\title{
48-72 Aylık çocuklar için Okul Öncesi İşitsel İşlemleme Testi (İŞTE)'nin geçerlik ve güvenirlik çalışması *
}

\section{Validity and reliability study of Preschool Auditory Processing Test (PAPT) for 48-72 months children}

\begin{abstract}
Makale Geçmişi
Geliş : : 17 Ağustos 2019

Düzeltme : 10 Şubat 2020

Kabul : 2 Mart 2020
\end{abstract}

\section{Makale Türü}

Araştırma Makalesi

\section{Article History}

Received : 17 August 2019

Revised : 10 February 2020

Accepted : 2 March 2020

Article Type

Research Article

\author{
Elif Küçükoğlu ${ }^{1}$, Alev Önder ${ }^{2}$, Özgül Polat ${ }^{3}$
}

Öz: İşitsel işlemleme süreci çocukların işittiklerini algılama, yorumlama, anlama ve birbiriyle ilişkilendirme şekilleriyle ilgili olan bilișsel becerilerdir. Bu çalıșma okul öncesi dönem çocukların işitsel işlemleme becerilerini değerlendirmek üzere geçerli ve güvenilir bir ölçme aracının geliştirilmesi amacıyla tasarlanmıştır. İşitme engeli olmayan, 48-72 aylık çocuklar için geliştirilen Okul Öncesi İşitsel İşlemleme Testi (ISSTE) listeleri, alan yazın taraması yapılarak hazırlanmıştır. Alan uzmanlarından alınan görüşler doğrultusunda test düzenlenmiș ve ardından Lawshe analizi uygulanarak yüzey ve kapsam geçerliliği sağlanmıştır $(\mathrm{KGO}=0.99, \mathrm{p}<0.05)$. Örneklem, yaş, cinsiyet ve gelir grupları göz önünde bulundurularak tabakalı örnekleme deseniyle oluşturulmuştur. Test, araştırmacı tarafından Istanbul ilinde okul öncesi eğitim alan 48-72 aylık 502 çocuğa uygulanmış, yapı geçerliliğinin sınanması için faktör analizi işlemleri öncesinde örneklem büyüklüğünün uygunluğunu belirleyebilmek amaciyla Kaiser-Meyer-Olkin Testi yapılmıştır $\left(\mathrm{KMO}=0.88 ; \chi^{2}{ }_{(231)}=6905.36 ; \mathrm{p}<0.01\right)$. Açımlayıcı faktör analizi sonucunda İSTE'nin öz değeri 1 ve 1 den fazla $(\lambda \geq 1)$ olan 4 faktörlü bir yapıdan oluştuğu görülmüştür. Alt testler iç tutarlılık katsayıları; Ses Bilgisel Farkındalık: Aynı Sesle Başlayanlar $(\alpha=0.84)$, Ses Bilgisel Farkındalık: Aynı Sesle Bitenler $(\alpha=0.86)$, Kısa Süreli İşitsel Bellek $(\alpha=0.94)$, İşitsel Ayırt Etme $(\alpha=0.78)$ ve İSTE toplamı $(\alpha=0.88)$ olarak hesaplanmıştır.

Anahtar Kelimeler: Okul öncesi, İşitsel işlemleme, İşitsel bellek, İşitsel dikkat, Ses bilgisel farkındalık,

Abstract: Auditory processing comprises the cognitive skills related to how children perceive, interpret, and understand what they hear and relate them with each other. This study is designed to develop a valid and reliable assessment device to evaluate the auditory processing skills of preschool children. Preschool Auditory Processing Test (IŞTE) lists developed for children of 48-72 months without impaired hearing have been prepared through a review of literature in the field. The test is issued according to the opinions taken from experts in the domain and then the face validity and content validity are ensured through Lawshe analysis $(C V R=0.99, \mathrm{p}<0.05)$. The researcher conducted the test on 502 children of 48-72 months, and a Kaiser-Meyer-Olkin Test was conducted to be able to determine the suitability of the sample size before factor analysis for construct validity test $\left(\mathrm{KMO}=0.88 ; \chi^{2}(231)\right.$ 6905.36; $\mathrm{p}$ <.01). As a result of exploratory factor analysis, it was seen that IŞTE consisted of a 4 factor structure with an eigenvalue of 1 and above $1(\lambda \geq 1)$. Internal consistency coefficients of sub-tests were calculated as Phonemic Awareness: Alliteration $(\alpha=0.84)$, Phonemic Awareness: Rhyming $(\alpha=0.86)$, Short-Term Auditory Memory $(\alpha=0.94)$, Auditory Discrimination $(\alpha=0.78)$, and total IŞTE $(\alpha=0.88)$.

Keywords: Preschool, Auditory processing, Auditory memory, Auditory attention, Phonemic awareness

DOI: $10.24130 /$ eccd-jecs. 1967202041186

\footnotetext{
Başlıca Yazar: Elif Küçükoğlu

* Bu çalışma başlıca yazarın Marmara Üniversitesi Eğitim Bilimleri Enstitüsü’nde sürdürdüğü doktora tezinden ve C-DRP 5567 numaralı Marmara Üniversitesi BAPKO Birimi projesinden üretilmistir.

${ }^{1}$ Marmara Üniversitesi, Atatürk Eğitim Fakültesi, Temel Eğitim Bölümü, ekurtulus@marmara.edu.tr, ORCID: 0000-0001-9419-734X

${ }^{1}$ Bahçeşehir Üniversitesi, Eğitim Bilimleri Fakültesi, Temel Eğitim Bölümü, alev.onder@es.bau.edu.tr, ORCID: 0000-0002-2736-4600

${ }^{1}$ Marmara Üniversitesi, Atatürk Eğitim Fakültesi, Temel Eğitim Bölümü, ozgul.polat@marmara.edu.tr, ORCID: 0000-0001-7426-5771
} 


\section{SUMMARY}

\section{Introduction}

Auditory processing comprises the cognitive skills related to how children perceive, interpret, and understand what they hear and relate them with each other. These skills include general knowledge, comprehension, similarities, analogy completion, arithmetic reasoning, verbal irrationalities, and directed orientation skills (Gardner, 1993). These skills may generally be grouped as follows (American Speech-Language-Hearing Association, 2005; Barker \& Purdy, 2016; Darıca \& Şipal, 2011; Dekerle, Meunier, N'Guyen, Gillet-Perret, Lassus-Sangosse \& Donnadieu, 2018; Girgin \& Kemaloğlu, 2017; Kujala \& Leminen, 2017; Møller, 2013; Sertel Berk \& Özkul, 2014):

Awareness: Ability to receive the sound signal and to recognize the sounds. This covers being aware of spoken sounds and environmental sounds.

Phonemic Awareness: This covers being aware of phonological properties and the structure of sound, similarities and differences.

Differentiating: Ability to recognize the changes in sound, distinguish mixed sounds, and identify different sounds and their characteristics. Ability to figure ground discrimination, discriminating relevant sound from irrelevant, recognizing auditory patterns, interpretation, and discriminating background noise, speech and environmental sounds.

Localizing: Ability to determine the direction of sound. This covers determining to what and where the sound belongs, and where it comes from.

Attention: It covers focusing attention and discriminating sounds with desired qualifications from others.

Memory: It is one of the most important learning skills. It covers listening, processing, storing verbal information carefully and recalling it from the storage when necessary.

Auditory Sequencing: Ability to remember those heard in a specific order, store those heard and remember.

There are assessment tools developed in the literature for auditory processing skills (Erbay, 2013; Karaman, 2013; Martin \& Brownell, 2005; Sarı \&Aktan Acar, 2013; Tepeli, Er Şahin \& Erbay, 2018). However, different groupings and classifications are made for such an important skill in terms of preparation for the listening and reading skills of preschool children. This study aims to evaluate the abilities of preschool children without impaired hearing, such as listening, recognizing, 
perceiving, and exhibiting proper behaviors to auditory stimuli, as well as evaluating them in terms of preparation for reading.

The purpose of this study is to develop a valid and a reliable assessment device to evaluate the auditory processing skills of preschool children. Based on this purpose, the study has two subpurposes:

1. Is the Preschool Auditory Processing Test developed for children of 48-72 months a valid tool?

2. Is the Preschool Auditory Processing Test developed for children of 48-72 months a reliable tool?

\section{Method:}

The study was conducted in two stages.

In the first stage: The face and content validity of Preschool Auditory Processing Test (IŞTE) was determined. The face validity of the test was evaluated based on the opinions of the researchers and experts of the domain. To determine the content validity, the semi-structured interview method was used to collect qualitative data for document analysis. As document analysis allows for converting qualitative data regarding the contents of the lists and their fitness for purpose into quantitative data (Baş \& Akturan, 2017), data collected from a semi-structured interview form provided the quantitative data for the calculation of content validity ratios developed by Lawshe (1975; akt. Yurdugül, 2005). At this stage, 7 experts of the domain were asked their opinions.

In the second stage: A general survey model of quantitative research methods was designed to conduct reliability and content validity, structure validity, and factor analysis processes (Best \& Kahn, 2017; Büyüköztürk, K1lıç Çakmak, Akgün, Karadeniz \& Demirel, 2016; DeVellis, 2014; Fraenkel, Wallen \& Hyun, 2015; Sönmez \& Alacapınar, 2017). At this stage of the study, the researcher collected data from 100 girls and 101 boys of 48-60 months, and 151 girls and 150 boys of 61-72 months attending kindergarten who were determined through random sampling method among kindergartens in Istanbul during the 2016 fall semester.

\section{Results}

Qualitative data were collected through document analysis method (face validity), and lists within the scope of test were prepared based on these data and subjected to Lawshe analysis by gathering the opinions of 7 experts of the domain (content validity). To determine the grouping titles of test items, Varimax Rotation was applied using Principal Component Analysis of exploratory factor 
analysis methods. It was seen that IŞTE consisted of a 4-factor structure with an eigenvalue of 1 and above $1(\lambda \geq 1)$. For the internal consistency of the test and its sub-dimensions, Cronbach alpha coefficients were calculated as Phonemic Awareness: Alliteration $(\alpha=0.84)$, Phonemic Awareness: Rhyming ( $\alpha=0.86$ ), Short Term Auditory Memory $(\alpha=0.94)$, Auditory Discrimination $(\alpha=0.78)$, and total İ̧TE $(\alpha=0.88)$. For item analysis processes, item analysis based on correlation and analysis based on $27 \%$ range mean group differences were conducted. In item remaining and item total score correlation calculations, it was found that all 21 lists were significant at a $\mathrm{p}<0.01$ level and in t-test conducted between lower and upper groups, all lists are significant at a $\mathrm{p}<0.01$ level.

\section{Conclusion and Discussion}

Findings of the study may present evidence regarding the validity and reliability of Preschool Auditory Processing Test. İŞTE consists of a 4-factor structure.

(1) Phonemic Awareness: The Alliteration Sub-Test arithmetic mean is 37.63 and standard deviation is 12.74. The minimum score obtained from Sub-Test is 11.00 maximum score is 60.00. Cronbach Alpha reliability coefficient is 0.84 .

(2) Phonemic Awareness: The Rhyming Sub-Test arithmetic mean is 43.76 and standard deviation is 17.01. The minimum score obtained from Sub-Test is 0.00 maximum score is 60.00. Cronbach Alpha reliability coefficient is 0.86 .

(3) The Short-Term Auditory Memory Sub-Test arithmetic mean is 33.44 and standard deviation is 11.28. The minimum score obtained from Sub-Test is 0.00 maximum score is 53.00. Cronbach Alpha reliability coefficient is 0.94 .

(4) The Auditory Discrimination Sub-Test arithmetic mean is 34.25 and standard deviation is 7.28. The minimum score obtained from Sub-Test is 0.00 maximum score is 51.00. Cronbach Alpha reliability coefficient is 0.78 . The ISSTE arithmetic mean is 148.42 and standard deviation is 1.58. The minimum score obtained from Sub-Test is 60.00 and maximum score is 215.00. Cronbach Alpha reliability coefficient is 0.88 . 


\section{GİRİŞ}

Doğumun ardından ciğerlere dolan hava ile çığllğa dönüşen ilk sesin, agulardan ses örüntülerine, kelimelerden cümlelere evrilerek konuşmaya dönüşmesi gelişim serüveninin önemli bir boyutudur. Anne karnında başlayan işitme serüveni, doğumla birlikte konuşma sesini ayırt etmeye dönüşür. İşittikçe kendi dilimizin yapısını kavrar ve sesleri doğru bir şekilde işlemleyip konuşmayı öğreniriz. Birinin sesini ve konuşmalarını fark edip dikkatini ona yönlendirmek (algılama), o sesi tanımak ve bu işitsel sinyalleri tanımlamak (kod çözme) ve kavrayış (anlama) süreci iletişim ve öğrenme sürecine dönüşür (Akarsu, 2017). Bu süreç eğitim yaşantısı ile birlikte okumayı öğrenme ile devam eder.

İşitme, havadaki moleküllerin salınımlarını daha detaylı algılaması için özel gelişmiş bir duyu sistemidir (Kemaloğlu, 2017; Møller, 2013). İşitme sistemi, bireyin çevresel ses ve uyaranları duyarak kendini koruyabilmesi gibi hayati bir fonksiyonu sağlaması yanında insanlar arası iletişim kurulmasında da ihtiyaç duyulan bir duyudur ve diğer duyu sistemlerine göre daha karmaşık bir yapıya sahiptir (İncesulu, 2017; Møller, 2013; Moore, 2014). İşitsel süreçlerin doğumdan önce başladığı ve özellikle doğumdan sonraki 30 gün içinde hızlı bir olgunlaşma yaşanırken merkezi işitsel yeteneklerin gelişmesi daha uzun zamana yayılır (Aamondt ve Wang, 2011; Atlı ve Beyazıt, 2015; Beaty ve Pratt, 2015; Bilavski, Shahar-Nissan, Pardo, Attias ve Amir, 2016; Dekerle, Meunier, N'guyen, Gillet-Perret, Lassus-Sangosse ve Donnadieu, 2018). Dekerle ve diğerleri (2018) ses niteliklerinin duyuşsal olarak kodlanmasının, işitsel uyarılmış potansiyelin gelişimine bağlı olarak, yaşla birlikte olgunlaştığını ifade etmektedirler.

İşitsel işlemleme, işitsel sinyallerin etkili ve yeterli bir şekilde merkezi sinir sistemi tarafindan alınması ve elektro fizyolojik işitsel sinyalden oluşan bu işitsel bilginin algısal olarak işlenmesi sürecidir (Bellis, 2002; Martin ve Brownell, 2005).

Bu süreç, konuşma ve karmaşık çevresel seslerin fiziksel özelliklerin analizinde rol oynayan beyin alanları ile sözcüksel-anlamsal ve daha yüksek seviyeli dilsel işlemeyle ilgili alanlar arasında bağlantı gerektirir (Boets, Wouters, van Wieringen ve Ghesquire, 2007; Liebenthal, Binder, Spitzer, Possing ve Medler, 2005; Scott, 2003).

İşitsel işlemleme süreci, çocukların işittiklerini algılama, yorumlama, anlama ve birbiriyle ilişkilendirme şekilleriyle ilgili olan bilişsel becerilerdir. Bu beceriler genel bilgiler, kavrama, benzerlikler, analojik tamamlama, aritmetik muhakeme, sözlü mantıksızlıklar ve yönlü oryantasyon becerilerini içermektedir (Gardner, 1993). Bu becerileri genel olarak şöyle gruplanabilir (American Speech-Language-Hearing Association, 2005; Barker ve Purdy, 2016; Darıca ve Şipal, 2011; Dekerle ve diğerleri, 2018; Girgin ve Kemaloğlu, 2017; Kujala ve Leminen, 2017; Møller, 2013; Sertel Berk ve Özkul, 2014): 
Farkındalık: Sesin olup olmadığ1 sinyalini alabilme, sesleri tanıma becerisidir. Konuşma seslerini, çevresel seslerin farkında olmayı içerir.

Ses Bilgisel Farkındalık: Sesin fonolojik özelliklerinin ve yapısının, benzerlik ve farklılıklarının da fark edilmesini içerir.

Ayırt etme: Sesteki değişimlerin farkına varma, karışı sesleri ayrıştırma, farklı sesleri ve özelliklerini ayırt etme becerisidir. Şekil zemin ayırımını, ilgili sesi ilgisizden ayırabilme, işitsel örüntüyü tanıma, anlamlandırma, arka plandaki gürültüyü, konuşma ve çevresel sesleri ayırt edebilme becerisidir.

Yerini belirtme: Sesin yönünü belirleme becerisidir. Sesin neye, nereye ait olduğunu ve nereden geldiğini belirlemeyi de içerir.

Dikkat: Dikkatini odaklama, istenilen nitelikteki sesleri diğerlerinden ayırt etmeyi içerir.

Bellek: En önemli öğrenme becerilerinden biridir. Sözel bilgiyi dikkatle dinleme, işlemleme, depolama ve gerektiğinde depodan geri çevirmeyi içerir.

İşitsel Ardışıklık: İşitilenleri kendi özel sırasında hatırlayabilme, duyduğunu saklayabilme ve hatırlayabilme becerisidir.

Alan yazında işitsel işlemleme becerilerine yönelik alan yazında geliştirilmiş ölçme araçları bulunmaktadır (Erbay, 2013; Karaman, 2013; Martin ve Brownell, 2005; Sar1 ve Aktan Acar, 2013; Tepeli, Er Şahin ve Erbay, 2018). Ancak okul öncesi çocukların dinleme ve okumaya hazırlık becerileri açısından oldukça önemli olan bu beceriye yönelik farklı gruplamalar ve sınıflamalar yapılmıştır. Bu çalışma ile özellikle işitme engeli olmayan okul öncesi çocukların işitsel uyaranları dinleme, onları fark etme, algılama ve uygun davranış gösterme gibi becerilerinin yanı sıra okumaya hazırlık açısından da değerlendirmesinin yapılması hedeflenmiştir.

Bu çalışmanın amacı okul öncesi dönem çocukların işitsel işlemleme becerilerini değerlendirmek üzere geçerli ve güvenilir bir ölçme aracının geliştirilmesidir. Bu amaca dayalı olarak çalışmanın iki alt amacı bulunmaktadır:

1. 48-72 aylık çocuklara yönelik olarak geliştirilen Okul Öncesi İşitsel İşlemleme Testi (İŞTE) geçerli bir araç mıdır?

2. 48-72 aylık çocuklara yönelik olarak geliştirilen Okul Öncesi İşitsel İşlemleme Testi (IŞTTE) güvenilir bir araç mıdır? 


\section{YÖNTEM}

$\mathrm{Bu}$ bölümde araştırma modeli, çalışma grubu, veri toplama araçları ve verilerin analizi yer almaktadır.

\section{Araştırma Modeli}

Çalışma iki aşamada gerçekleştirilmiştir.

Birinci aşamada: Okul Öncesi İşitsel İşlemleme Testi (İSTE)'nin yüzey ve kapsam geçerliliği saptanmıştır. Testin yüzey geçerliliği araştırmacı ve alan uzmanlarında alınan görüşlerle değerlendirilmiştir. Kapsam geçerliliğinin belirlenmesi amacıyla, doküman analizine nitel veriler toplanması için yarı yapılandırılmış görüşme yöntemi kullanılmıştır. Doküman analizi, listelerin içerikleri ve amaca uygunlukları ile ilgili nitel verilerin nicel verilere dönüştürülmesine imkân tanıdığından (Baş ve Akturan, 2017), yarı yapılandırılmış görüşme formundan alınan veriler Lawshe (1975; akt. Yurdugül, 2005) tarafından geliştirilen kapsam geçerlilik oranlarının hesaplanması için gerekli nicel verileri sağlamıştır.

İkinci aşamada: Güvenilirlik ve kapsam geçerliliği, yapı geçerliliği ve faktör analizi işlemlerini yapmak amacıyla nicel araştırma yöntemlerinden genel tarama modelinde tasarlanmıştır (Best ve Kahn, 2017; Büyüköztürk, Kılıç Çakmak, Akgün, Karadeniz ve Demirel, 2016; DeVellis, 2014; Fraenkel, Wallen ve Hyun, 2015; Sönmez ve Alacapınar, 2017).

\section{Evren ve Örneklem}

Milli Eğitim Bakanlığı'nın 2015-2016 verilerine göre 2010-2011 yıllarında doğan (48-72 aylık) ve okul öncesi eğitim alan toplam çocuk sayısı İstanbul ilinde ise 161335'dir (TC Milli Eğitim Bakanlığ1 Strateji Geliştirme Başkanlığı, 2016). Bu araştırmada, örneklem büyüklügüünün belirlenmesinde İstanbul'da okul öncesi eğitim alan çocukların nüfusu esas alınmıştır. Yazıcıoğlu ve Erdoğan (2004), evren büyüklügünün 1.00.000 olması halinde $\alpha=0.05+0.05$ örnekleme hatası için evrenden çekilmesi gereken örneklem büyüklügüunü 384 olarak belirtmektedir. Guilford (1954)'a göre ölçek geliştirme çalışmalarında örneklem sayısının en az 200 olması gerekmektedir. Comrey ve Lee (1992) ise 500 kişinin çok iyi bir örneklem grubu olduğunu belirtmişlerdir. Child (2006), madde sayısı veya gözlenen değişken sayısının 5 katı örneklem büyüklüğü olması gerektiğini, Tavşancıl (2002) madde sayısının 5-10 katı bir örneklem büyüklüğünün yeterli olacağını ifade etmektedir. Bu değerlendirmeler göz önünde bulundurularak örneklem grubuna 48-60 aylık (2011 doğumlu) 201 çocuk, 61-72 aylık (2010 doğumlu) 301 çocuk olmak üzere toplam 502 çocuk alınmıştır. 
Örneklem grubu, 2016 yılı güz döneminde İstanbul ili Anadolu yakasındaki Ataşehir, Çekmeköy, Kadıköy, Kartal, Maltepe, Sarıazi, Ümraniye, Üsküdar ilçeleri ile Avrupa yakasındaki Avcılar, Bakırköy, Beylikdüzü, Fatih, Kağıthane ilçelerindeki anaokulları arasından seçkisiz örnekleme yöntemi ile belirlenen anaokullarına devam eden 48-72 aylık 502 çocuktan oluşmaktadır. Örneklem grubundaki çocuklar, öğretmenlerinin beyanları doğrultusunda özel eğitime gereksinim duymayan, normal gelişim gösteren ve uygulama yapıldığı dönemde gribal bir sağlık problemi yaşamayan, işitme ile ilgili teşhis ve tedavisi olmayıp, işitme cihazı kullanmayan çocuklardır.

Örneklem, yaş, cinsiyet ve gelir grupları göz önünde bulundurularak tabakalı örnekleme deseniyle oluşturulmuştur. Böylelikle, bu değişkenler açısından dengeli bir dağılan bir grup (Gliner, Morgan ve Leech, 2009) elde edilmiştir.

Örneklem grubunda yer alan çocuklanın demografik özelliklerine ilişkin bilgiler Tablo 1'de sunulmuştur.

Tablo 1. Örneklem Grubunda Yer Alan Çocukların Demografik Özellikleri

\begin{tabular}{|c|c|c|c|c|c|}
\hline & & \multicolumn{3}{|c|}{ Aile Tarafından Tanımlanan Gelir Düzeyi } & \multirow{2}{*}{-Toplam } \\
\hline & & Düşük & Orta & Yüksek & \\
\hline \multirow{3}{*}{$\begin{array}{l}\text { 48-60 aylık } \\
\text { (2011 } \\
\text { Doğumlu) }\end{array}$} & $\mathrm{K}_{1 z}$ & 20 & 60 & 20 & 100 \\
\hline & Erkek & 20 & 61 & 20 & 101 \\
\hline & Toplam & 40 & 121 & 40 & 201 \\
\hline \multirow{3}{*}{$\begin{array}{l}\text { 61-72 Aylik } \\
\text { (2010 } \\
\text { Doğumlu) }\end{array}$} & $\mathrm{K}_{1 z}$ & 30 & 91 & 30 & 151 \\
\hline & Erkek & 30 & 90 & 30 & 150 \\
\hline & Toplam & 60 & 181 & 60 & 301 \\
\hline Toplam & & 100 & 302 & 100 & 502 \\
\hline
\end{tabular}

Tablo 1. incelendiğinde çalışma grubundaki 48-60 aylık 2011 doğumlu 100 çocuğun kız, 101 çocuğun erkek olduğu, ayrıca 40 çocuğun ailesini kendilerini düşük gelirli, 121 çocuğun ailesini orta gelirli ve 40 çocuğun ailesini yüksek gelirli olarak tanımladıkları görülmektedir. Çalışma grubundaki 61-72 aylık 2010 doğumlu 151 çocuk kız, 150 çocuk erkektir. Ayrıca bu gruptaki 60 çocuğun ailesini kendilerini düşük gelirli, 181 çocuğun ailesini orta gelirli ve 60 çocuğun ailesini yüksek gelirli olarak tanımlamışlardır. 


\section{Veri Toplama Araçları}

Çalışmada veri toplama aracı olarak; araştırmacı tarafından geliştirilen 48-72 aylık çocuklara yönelik “Okul Öncesi İşitsel İşlemleme Testi (İŞTE)” kullanılmıştır. Araştırmacı tarafından geliştirilen Okul Öncesi İşitsel İşlemleme Testi (İŞTE)'nin, kriter geçerliliğini test etmek amacıyla Erken Okuryazarlık Becerilerini Değerlendirme Aracı-Ses Bilgisel Farkındalık Becerilerini Değerlendirme Alt Testi (EOBDA-Ses), Marmara İlk Öğretime Hazır Oluş Ölçeği - Uygulama Formu: Ses Alt Ölçeği (MİHÖ-Ses) ve Selçuk İşitsel Muhakeme ve İşlem Becerileri Testi (SİMİBT) kullanılmıştır.

\section{Okul Öncesi İsitsel İslemleme Testi (İŞTE)}

Okul Öncesi İşitsel İşlemleme Testi (İŞTE), araştırma kapsamında 48-72 aylık çocuklara araştırmacı tarafindan birebir uygulanacak form ve ses materyali olarak hazırlanmıştır. İşitme engeli olmayan, 48-72 aylık çocuklarla ses uyaranlarının olmadığı, dikkat dağıtıcı unsurlardan uzak, ışık alan, masa başında bir ortamda araştırmacı tarafından uygulanmış ve ardından geçerlilik güvenilirlik analizleri yapılmıştır.

\section{Erken Okuryazarlık Becerilerini Değerlendirme Aracı (EOBDA)-Ses Bilgisel Farkındalık}

\section{Becerilerini Değerlendirme Alt Testi}

Erken Okuryazarlık Becerilerini Değerlendirme Aracı (EOBDA) okul öncesi dönem çocuklarının erken okuryazarlık becerilerini değerlendirmek amacıyla Karaman tarafindan 2013 yllinda geliştirilmiştir (Karaman, 2013). Erken Okuryazarlık Becerilerini Değerlendirme Aracı içerisinde beş alt test ve toplam 96 madde bulunmaktadır. Bu alt testler; ses bilgisel farkındalık becerilerini değerlendirme, yazı farkındalığı öyküyü anlama, görselleri eşleştirme ve yazı yazma öncesi becerileri değerlendirme olarak belirlenmiştir. Çalışmada kullanılan Ses Bilgisel Farkındalık Alt testinin beş faktörlü yapıdadır ve toplam 53 maddeden oluşmaktadır. Doğru yanıtlar için "1” yanlış yanıtlar için “0” verilerek değerlendirilen alt testin KR20 güvenirlik değeri 0.91'dir (Karaman ve Güngör-Aytar, 2016).

\section{Marmara İlköğretime Hazır Oluş Ölçeği-Uygulama Formu: Ses Çalışmaları Alt Ölçĕ̆i}

Marmara İlköğretime Hazır Oluş Ölçeği, Polat-Unutkan tarafindan 60-78 aylık çocukların her gelişim alanında ve temel becerilerde ilköğretime ne düzeyde hazır olduğunu tespit etmek amacıyla Türk çocuklarına özgü olarak geliştirilmiş ve standardizasyonu yapılmıştır (Polat-Unutkan, 2003). Ölçek Uygulama Formu ve Gelişim Formlarından oluşmaktadır. Uygulama Formu Matematik, Fen, Ses, Çizgi ve Labirent çalışmaları olmak üzere 5 alt test ve 74 sorudan oluşmaktadır. Gelişim formu, Zihinsel ve Dil Gelişimi, Sosyo-Duygusal Gelişim, Fiziksel Gelişim ve Özbakım Becerileri olmak üzere 4 bölüm ve 153 maddeden oluşmaktadır. Çalışmada kullanılan Ses Çalışmaları Alt Ölçeği 8 
maddelidir. Alt Ölçek değerlendirilirken doğru yanıt için “1” puan verilirken yanlış yanıtlar puanlanmaz. Alt ölçeğin Cronbach Alpha güvenirlik katsayısı 0.88'dir (Polat-Unutkan, 2003; PolatUnutkan ve Oktay, 2004, Polat, 2013).

\section{Selçuk İşitsel Muhakeme ve İşlem Becerileri Testi}

Selçuk İşitsel Muhakeme ve İşlem Becerileri Testi (SIMİBT), Tepeli, Er Şahin ve Erbay tarafından 60-72 aylık çocukların işitsel muhakeme ve işlem becerilerini değerlendirmek amacıyla geliştirilmiştir. Geçerlik güvenirlik çalışması için Konya ili Meram, Karatay ve Selçuklu merkez ilçelerine bağlı resmi ve özel okul öncesi eğitim kurumlarına devam eden 5-6 (60-72 ay) yaşında 400 çocuktan toplanan verilerle yapılmıştır. SİMIBT geliştirilirken ölçeğin güvenirliğinin test edilmesinde, güvenirlik katsayısı, test tekrar test ve puanlayıcılar arası uyum korelasyon değerleri; geçerliğinin test edilmesinde ise uzman görüşü, madde analizi, açımlayıcı faktör analizi, doğrulayıcı faktör analizi ve alt test korelasyon değerleri hesaplanmıştır. SIMIBTT altı faktörlü yapıdadır (Genel Bilgi, Aritmetik Muhakeme, Benzerlikler, Sözel Anlamsızlıklar, Analojik Tamamlama ve Nedensel Muhakeme). SİMIBT’in Aritmetik Muhakeme alt testi (0.69) hariç diğer alt test ve toplam test güvenirlik katsayılarının 0.70 ile 0.87 arasında değişmekte olup, çalışmada kullanılan toplam test puanı için (31 madde) güvenirlik katsayısı $0.87^{\prime}$ dir.

\section{Verilerin Analizi}

Uygulamalardan elde edilen veriler SPSS 21 paket programı kullanılarak çözümlenmiştir. Manidarlıklar minimum $\mathrm{p}<0.05$ düzeyinde sınanmış, diğer manidarlık düzeyleri ayrıca belirtilmiş ve bulgular araştırmanın amaçlarına uygun olarak tablolar halinde verilmiştir.

Doküman analizi yöntemi ile nitel veriler toplanmış (yüzey geçerliliği) ve bu veriler kodlanarak Lawshe analizine tabii tutulmuştur (kapsam geçerliliği). Test maddelerinin hangi başlıklar altında gruplanabileceğini saptamak için açımlayıcı faktör analizi yöntemlerinden Temel Bileşenler Analizi yöntemi kullanılarak Varimax Rotasyonu yapılmıştır. Testin ve alt boyutlarının iç tutarlığ için Cronbach alpha katsayısı hesaplanmış; madde analizi işlemleri için korelasyona dayalı madde analizi ve alt-üst \%27’lik grup ortalamaları farkına dayalı analiz yapılmıştır. 


\section{BULGULAR}

\section{Birinci Aşama: Alt Boyutların Belirlenmesi}

İlgili literatür incelenerek; seslerin fark edilmesi, sesleri arasındaki farklılığı ayırt etme, seslerin yerini belirleme, duyduğu bir sesi ve kelimeyi hatırlama, belli bir düzen içinde hatırlama, sesli ve sessiz fonem kullanımına yönelik (American Speech-Language-Hearing Association, 2005; Banai ve Yifat, 2016; Darıca ve Şipal, 2011; Girgin ve Kemaloğlu, 2017; Kesgül-Sercan, 2015; Wodruff Car, Tierney, White-Schwoch, ve Kraus, 2016) listeleri oluşturulmuştur. Her bir liste beklenen işleme uygun olarak ses veya kelime serileri içermektedir. Listelerde yer verilen kelimeler belirlenirken, alan yazında okul öncesi sınıflarda kullanılan hikâyeler ve 1. sınıf okuma öğretimi kitaplarında yer alan kelimeler taranmıştır. Bu kelimeler arasından çocukların günlük yaşantılarında aşina oldukları kelimeler seçilerek test içeriğine alınmıştır.

\section{İkinci Aşama: Geçerlilik Hesaplamaları}

\section{Görünüş Geçerliliği}

Görünüş geçerliğinin ilk aşaması araştırmacı tarafından mantıksal tasarımla sağlanmıştır. Araştırmacı tarafından işitsel işlemleme becerilerine yönelik ses ve kelime listeleri hazırlanmıştır. Listeler uzman görüşüne sunulmuş, alınan geri bildirimlere göre her listede düzenlemeler yapılarak görünüş geçerliği sağlanmıştır (Şencan, 2005).

\section{Kapsam Geçerliliği}

Kapsam geçerliliği sınanması için hazırlanmış olan listelerdeki kelime ve ses kayıtları için 7 alan uzmanından görüş alınmıştır. Lawshe tekniği ile (Çam ve Baysan-Arabacı, 2010; Yurdugül, 2005) uzmanlardan, yarı yapılandırılmış görüşme formunda uygun, uygun değil ve değiştirilerek kullanılabilir şeklinde görüş sorulmuş; elde edilen nitel veriler, kodlanarak puana dönüştürülmüsstür. Böylelikle maddelerinin her biri için kapsam geçerlik oranları hesaplanmıştır. İşitsel işlemleme becerilerine yönelik 22 listenin her birinin kapsam geçerliliğinin belirlenmesi amacıyla 7 alan uzmanı tarafından değerlendirme yapılmıştır. 7 alan uzmanına gönderilen listeler için $p<0.05$ anlamlılık düzeyine göre kapsam geçerlilik oranının (KGO) minimum değeri 0.99 olarak kabul edilmiş (Venezio ve Hooper, 1997; Akt. Yurdagül, 2005); bu değerin altında kalan maddeler çıkarılmıştır. Buna göre

1. Çevresel sesleri tanıma listesinde 15 ses yer almaktadır. Alan uzmanlarına dinletilen ve uygun görülmeyen 1 ses listeden çıkartılmıstır $(\mathrm{KGO}=0.71)$. Kalan 14 ses için yeniden hazırlanan listedeki tüm sesler uygun görülmüştür $(\mathrm{KGO}=1.00)$. 
2. Çevresel seslerin yerini yönünü tahmin etme listesinde 10 ses yer almaktadır. Bu sesler alan uzmanlarına dinletilmiş ve uygun görülmeyen 1 ses listeden çıkartılmıştır $(\mathrm{KGO}=0.71)$. Kalan 9 ses için yeniden hazırlanan listede tüm sesler uygun görülmüştür $(K G O=1.00)$.

3. Aynı kelime çiftlerini ayırt etme için hazırlanan listede 30 kelime çiftinden aynı olanların ayırt edilmesi istenmiş; bu kelime çiftleri alan uzmanlarına verilerek ve uygun görülmeyen 1 kelime çifti listeden çıkartılmıştır $(\mathrm{KGO}=0.71)$. Kalan 29 kelime çifti için yeniden hazırlanan listedeki tüm kelime çiftleri uygun görülmüş̧ür $(K G O=1.00)$.

4. Hedef kelimeyi fark etme listesinde 50 kelimenin arasindan "Alet" kelimesini bulunmas1 istenmiş; kelime listesi alan uzmanlarına verilerek görüşleri alınmıştır. Listedeki tüm kelimeler uygun görülmüştür (KGO=1.00).

5. Ses bilgisel farkındalık alt boyutunda MEB Talim Terbiye Kurulu (2016) tarafindan İlköğretim 1. Sınıf Türkçe ders programındaki 6 ses grubunun ilk sesleri (e, i, k, m, ç, f) alınmış ve aynı sesle başlayan ve aynı sesle biten kelime listelerinin oluşturulmasında kullanılmıştır. Ses bilgisel farkındalık alt boyutunda 12 liste hazırlanmıştır. Her listeye 10 kelime alınmıştır; bu kelimelerin 3 tanesi istenen ses özelliğine uygun olup 7 tanesi farklı sesle başlayan kelimelerdir. Kelimeler uzmanlarına verilerek görüşleri alınmıştır. Listelerde yer alan tüm kelimeler uygun görülmüş ve 12 adet "ses bilgisel farkındalık listesi” bu haliyle düzenlenmiştir $(\mathrm{KGO}=1.00)$.

6. İşitsel bellek listelerine, 16 diziden oluşan sıralı rakam listesi, 10 diziden oluşan ters sıralı rakam listesi, 10 diziden oluşan sıralı kelime listesi ve 6 metin-soru dizisinden oluşan metin listesi olmak üzere 4 liste hazırlanmıştır.

Rakam dizisini sıralı söyleme listesindeki 6 dizi alan uzmanları tarafindan uygun görülmeyerek $(\mathrm{KGO}=0.14)$ listeden çıkarılmış; kalan 10 rakam dizisi ile liste yeniden düzenlenmiştir $(\mathrm{KGO}=1.00)$.

Rakam dizisini tersten sıralı söyleme listesindeki 3 dizi, alan uzmanları tarafindan uygun görülmeyerek $(\mathrm{KGO}=0.14)$ listeden çıkarılmış; kalan 7 rakam dizisi ile liste yeniden düzenlenmiştir $(\mathrm{KGO}=1.00)$.

Kelime dizisini sıralı söyleme listesinde yer alan 10 kelime dizisi alan uzmanları tarafından uygun görülmüştür $(\mathrm{KGO}=1.00)$.

Metin hatırlama listesinde yer alan 10 kelime dizisi alan uzmanları tarafindan uygun görülmüştür $(\mathrm{KGO}=1.00)$. 
7. İşitsel ardışıklık listelerinde, cümle listesi ve görev dizisi listesi hazırlanmıştır. Cümleyi tekrar etme listesinde yer alan 12 cümle, alan uzmanları tarafindan uygun görülmüștür $(\mathrm{KGO}=1.00)$. Ardış1k görev listesinde ise 9 görev dizisi belirlenmiş; alan uzmanları tarafindan uygun görülmeyen 1 görev listeden çıkartılmıss (KGO=0.71); kalan 8 görev için yeniden hazırlanan listedeki tüm kelime çiftleri uygun görülmüştür $(\mathrm{KGO}=1.00)$.

7 uzman için kapsam geçerlik ölçütleri doğrultusunda $\mathrm{p}<0.05$ anlamlılık düzeyinde minimum kapsam geçerlik ölçütleri amaç, içerik ve tasarım boyutlarında 0.99 üzeri değere ulaşmış ve 22 adet listenin değerlendirilmesi sonucunda kapsam geçerlik oranı $>$ kapsam geçerlik indeksi sağlandığından kapsam geçerliği istatistiksel olarak anlamlı bulunmuştur.

\section{Yapı Geçerliliği}

Geçerlilik bir ölçme aracının ölçmeyi amaçladığı özelliği, başka herhangi bir özellikle karıştırmadan ölçebilme derecesidir (Büyüköztürk, Kılıç Çakmak, Akgün, Karadeniz ve Demirel, 2016; De Vellis, 2014; Fraenkel, Wallen, ve Hyun, 2015; Karakoç ve Dönmez, 2014; Sönmez ve Alacapınar, 2017). Araştırmacı tarafından geliştirilen ISSTTE'nin 48-70 aylık çocukların işitsel işlemleme becerilerini değerlendirebilen bir araç olarak ölçme derecesini belirlemek amacıyla geçerlilik analizleri yapilmıştır.

IŞTE faktör analizi işlemleri öncesinde örneklem büyüklügünün uygunluğunu belirleyebilmek amacıyla Kaiser-Meyer-Olkin (KMO) Testi yapılmıştır. KMO test sonucunun 0.60'dan büyük olması faktör analizi için uygunluk göstergesidir.

Tablo 2. 48-70 Aylık Çocuklar İçin Okul Öncesi İşitsel İşlemleme Testi (IŞSTE)'nin Faktör Analizine Uygunluğuna Dair Veriler

\begin{tabular}{l|ll}
\hline $\begin{array}{l}\text { Kaiser-Meyer-Olkin (KMO) } \\
\text { Örneklem Ölçüm Değer Yeterlilĭği }\end{array}$ & 0.88 \\
\hline & Ki-Kare & 6905.36 \\
Bartlett Testi & Sd & 231 \\
& $\mathrm{P}$ & 0.00 \\
\hline Cronbach's Alpha & 0.78 \\
\hline
\end{tabular}

Tablo 2'de görüldüğü gibi KMO değeri 0.88 olarak tespit edilmiştir ve bu değer ile örneklem büyüklüğunün “iyi” (Alpar, 2013) olduğu sonucuna varılmıştır. Ayrıca Bartlett Küresellik testi sonuçları incelendiğinde ki-kare değerinin $\left(\chi^{2} \quad\right.$ (231) $\left.=6905.36 ; \mathrm{p}<0.01\right)$ anlamlı olduğunu göstermektedir. Cronbach’s Alpha değeri 0.78 olduğundan verilerinin güvenirliğinin yüksek olduğu söylenebilir. Büyüköztürk (2010) faktör yük değerinin 0.70 ve üzerinde olmas1 gerektiğini belirtmektedir. Bu bağlamda verilerin çok değişkenli normal dağılımdan geldiğini ve değişkenler arasında faktör analizi yapmaya yeterli bir ilişkinin olduğu söylenebilir. 
Ölçek maddelerinin hangi başlıklar altında gruplanabileceğini saptamak için açımlayıcı faktör analizi yöntemlerinden Temel Bileşenler Analizi yöntemi kullanılır (Şencan, 2005; Tavşancıl, 2002). Birden fazla faktör (alt boyut) ortaya çıarmak amaçlanıyorsa, dik açılı döndürme biçimlerinden biri olan Varimax Rotasyonu yapilır (Şencan, 2005). ISSTE faktör desenini ortaya koymak amaciyla faktörleştirme yöntemi olarak temel bileşenler analizi; döndürme yöntemi olarak da dik döndürme yöntemlerinden maksimum değişkenlik (varimax) seçilmiştir.

Tablo 3 . İSTE Faktör Yapiları

\begin{tabular}{llll}
\hline Faktör & Özdeğer & Varyans Yüzdesi & Toplam Varyans \\
\hline Faktör 1 & 7.27 & 33.04 & 33.04 \\
Faktör 2 & 3.27 & 14.84 & 47.88 \\
Faktör 3 & 1.87 & 8.48 & 56.36 \\
Faktör 4 & 1.35 & 6.15 & 62.51 \\
Faktör 5 & 1.12 & 5.33 & 67.84 \\
\hline
\end{tabular}

Tablo 3'de açımlayıcı faktör analizi sonucunda IŞTE'yi oluşturan 22 liste için öz değeri 1'in üzerinde 5 bileşen olduğu görülmektedir. Toplam varyansın \%33.04'ünü birinci, \%14.84'ünü ikinci, \%8.48'ini üçüncü, \%6.15'ini dördüncü, \%5.33’ünü beşinci bileşenin açıkladığı, toplam varyansa ise \%67.84 oranında katkı sağladığı görülmektedir.

İSTE'nin faktör sayısı belirlendikten sonra maddelerin faktörlere dağılımları incelenmiştir. Maddelerin hangi faktörde güçlü korelasyonunun olduğunu belirlemek için döndürülmüş bileşenler matrisi (rotated compenent matrix) oluşturularak maddelerin binişiklik ve faktör yük değerlerinin kabul düzeyini karşılayıp karşılamadığı incelenmiştir. Yapılan döndürülmüş Bileşenler matrisinde en düşün faktör değeri 0.52 bulunmuştur. Şencan (2005) tarafında belirtildiğine göre Kim Yin faktör yükü değerinin örneklem büyüklüğü ile ilişkili olduğunu söylemektedir. Buna göre, faktör yükü 0.30 olan maddelerin ölçeğe alınması için örneklem büyüklüğünün en az 350 kişi; 0.40 faktör yükü için 200 kişi; 0.50 faktör yükü için 120 kişi; 0.60 faktör yükü için 85 kişi ; 0.70 faktör yükü için 60 kişilik bir örneklemin yeterli olacağı ifade edilmiştir. Çalışmanın örneklem grubu 502 olup en düşük faktör yürü 0.52 'dir. Yapılan analiz sonucunda 5. faktörün tek maddeden oluştuğu görülmüş ve bu nedenle madde testten çıkartılarak faktör analizi işlemleri tekrarlanmıştır.

Tablo 4. İSTTE Tekrarlanan Analizde Faktör Yapıları

\begin{tabular}{llll}
\hline Faktör & Özdeğer & $\begin{array}{l}\text { Varyans } \\
\text { Yüzdesi }\end{array}$ & $\begin{array}{l}\text { Toplam } \\
\text { Varyans }\end{array}$ \\
\hline Faktör 1 & 7.24 & 34.49 & 34.49 \\
Faktör 2 & 3.21 & 15.30 & 49.79 \\
Faktör 3 & 1.83 & 8.67 & 58.46 \\
Faktör 4 & 1.34 & 6.38 & 64.85 \\
\hline
\end{tabular}


Tablo 4'de tekrarlanan açımlayıcı faktör analizi sonucunda IŞTE'yi oluşturan 21 madde için öz değeri 1'in üzerinde 4 bileşen olduğu görülmektedir. Toplam varyansin \%33.49’unu birinci, \%15.30’unu ikinci, \%8.67'sini üçüncü, \%6.38'ini dördüncü bileşenin açıkladığ1, toplam varyansa ise \%64.85 oranında katkı sağladığı görülmektedir.

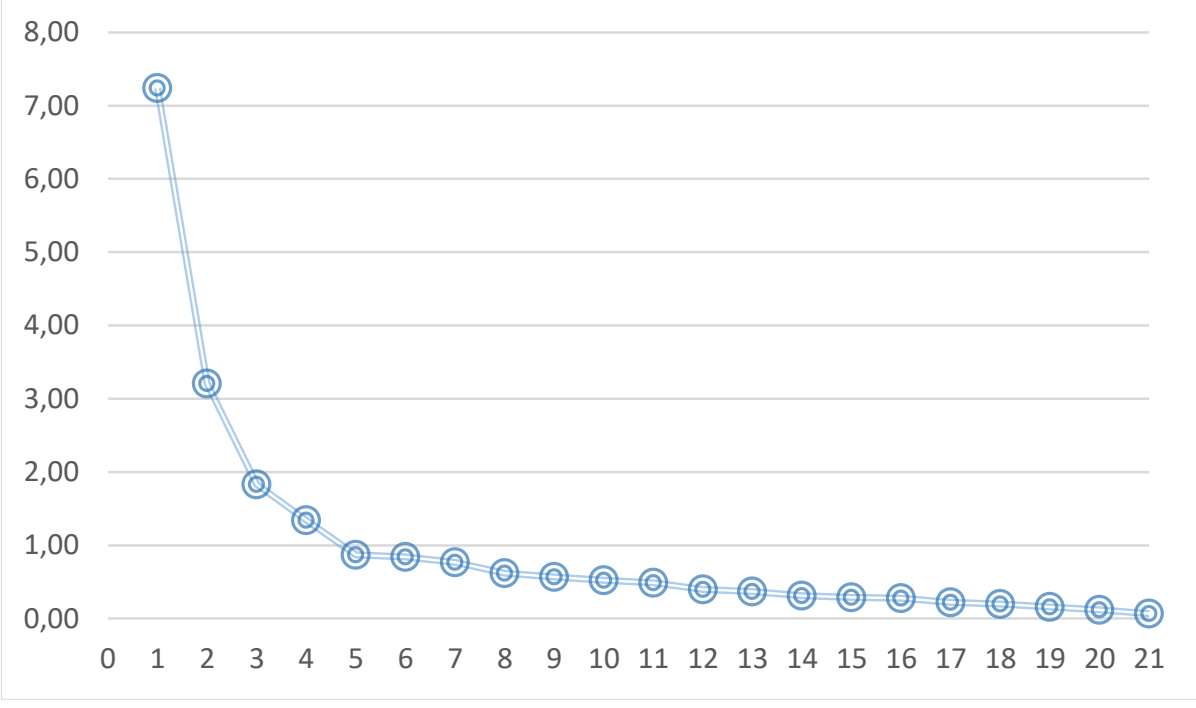

\section{Şekil 1. İSTE Dağlım Grafiği}

Şekil 1'de görüldüğü gibi, İ̧STE'deki dört faktörün öz değerleri sırasıyla faktör 1 için 7.24; faktör 2 için 3.21; faktör 3 için 1.83 ve faktör 4 için 1.34'tür. Öz değeri 1 ve 1 den fazla $(\lambda \geq 1)$ olan 4 faktör olduğundan bu dört faktör seçilmiştir.

Tablo 5. İŞTE Tekrarlanan Döndürülmüş Bileşenler Matrisi Tablosu

\begin{tabular}{lllll}
\hline \multirow{2}{*}{ Maddeler } & \multicolumn{3}{l}{ Döndürülmüş Faktör Yük Değerleri } & \\
\cline { 2 - 4 } & Faktör 1 & Faktör 2 & Faktör 3 & Faktör 4 \\
\hline "ç" sesi ile biten kelimeler & 0.90 & & \\
"m” sesi ile biten kelimeler & 0.90 & & \\
"f" sesi ile biten kelimeler & 0.87 & & \\
"k" sesi ile biten kelimeler & 0.87 & & \\
"i" sesi ile biten kelimeler & 0.79 & & \\
"e” sesi ile biten kelimeler & 0.73 & & \\
"e" sesi ile başlayan kelimeler & & 0.80 & \\
"k" sesi ile başlayan kelimeler & & 0.78 & \\
\hline
\end{tabular}


Tablo 5. İ̧̧TE Tekrarlanan Döndürülmüş Bileşenler Matrisi Tablosu-devamı

\begin{tabular}{|c|c|c|c|c|}
\hline \multirow{2}{*}{ Maddeler } & \multicolumn{4}{|c|}{ Döndürülmüş Faktör Yük Değerleri } \\
\hline & Faktör 1 & Faktör 2 & Faktör 3 & Faktör 4 \\
\hline “i”" sesi ile başlayan kelimeler & & 0.70 & & \\
\hline "m" sesi ile başlayan kelimeler & & 0.68 & & \\
\hline "ç" sesi ile başlayan kelimeler & & 0.59 & & \\
\hline "f" sesi ile başlayan kelimeler & & 0.52 & & \\
\hline Kelime dizisi tekrarlama & & & 0.79 & \\
\hline Söyleneni sıra ile yapma & & & 0.67 & \\
\hline Rakam dizisini sıralı söyleme & & & 0.66 & \\
\hline Kelime dizisini sıralı söyleme & & & 0.64 & \\
\hline Metin hatırlama & & & 0.62 & \\
\hline Rakam dizisini tersten sıralı söyleme & & & 0.52 & \\
\hline Sesin yerini/yönünü tahmin etme & & & & 0.74 \\
\hline Çevresel sesleri tanıma & & & & 0.68 \\
\hline Aynı kelime çiftlerini fark etme & & & & 0.62 \\
\hline
\end{tabular}

Tablo 5'de yapılan analiz sonucunda "ç" sesi ile biten kelimeler, " $\mathrm{m}$ " sesi ile biten kelimeler, " $\mathrm{f}$ " sesi ile biten kelimeler, " $k$ " sesi ile biten kelimeler, "i" sesi ile biten kelimeler, "e" sesi ile biten kelimeler maddelerinin birinci faktörde; "e" sesi ile başlayan kelimeler, "k" sesi ile başlayan kelimeler, "i" sesi ile başlayan kelimeler, "m" sesi ile başlayan kelimeler, "ç" sesi ile başlayan kelimeler, "f $\mathrm{f}$ ' sesi ile başlayan kelimeler maddelerinin ikinci faktörde; Kelime dizisi tekrarlama, Söyleneni sıra ile yapma, Rakam dizisini sıralı söyleme, Metin hatırlama, Rakam dizisini tersten sıralı söyleme maddelerinin üçüncü faktörde; Sesin yerini/yönünü tahmin etme, Çevresel sesleri tanıma, Aynı kelime çiftlerini fark etme maddelerinin dördüncü faktör altında toplandığı görülmektedir. Faktör yük değerlerinin birinci faktör için 0.90 ile 0.73 arasında; ikinci faktör için 0.80 ile 0.52 arasında; üçüncü faktör için 0.79 ile 0.52 arasında; dördüncü faktör için 0.74 ile 0.62 arasında değiştiği görülmektedir. Faktör yük değerlerinin “ç" sesi ile başlayan kelimeler, "f” sesi ile başlayan kelimeler ve Rakam dizisini tersten sıralı söyleme maddeleri dışında iyiden mükemmele doğru nitelendirilebilir (Comrey ve Lee, 1992).

Literatür taramasında elde edilen bilgiler ışı̆̆ında belirlenen 4 faktör, içeriklerine uygun bir şekilde yeniden isimlendirilmiştir. 
Tablo 6. İ̧̧TE Alt Faktörlerinin Korelasyon Matrisi

\begin{tabular}{|c|c|c|c|c|c|}
\hline Faktör & $\begin{array}{l}\text { Faktör 1: } \\
\text { Ses Bilgisel } \\
\text { Farkındalık: } \\
\text { Aynı Sesle } \\
\text { Başlayanlar }\end{array}$ & $\begin{array}{l}\text { Faktör 2: } \\
\text { Ses Bilgisel } \\
\text { Farkındalık: } \\
\text { Aynı Sesle } \\
\text { Bitenler }\end{array}$ & $\begin{array}{l}\text { Faktör 3: } \\
\text { Kısa Süreli } \\
\text { İşitsel } \\
\text { Bellek }\end{array}$ & $\begin{array}{l}\text { Faktör 4: } \\
\text { İşitsel Ayırt } \\
\text { etme }\end{array}$ & Toplam \\
\hline $\begin{array}{l}\text { Faktör 1: Ses Bilgisel Farkındalık: } \\
\text { Aynı Sesle Başlayanlar }\end{array}$ & 1 & $0.31 * *$ & $0.17 * *$ & $0.40 * *$ & $0.54 * *$ \\
\hline $\begin{array}{l}\text { Faktör 2: Ses Bilgisel Farkındalık: } \\
\text { Aynı Sesle Bitenler }\end{array}$ & & 1 & $0.60 * *$ & $0.33^{* *}$ & $0.82^{* *}$ \\
\hline Faktör 3: Kısa Süreli İşitsel Bellek & & & 1 & $0.18^{* *}$ & $0.79 * *$ \\
\hline Faktör 4: İşitsel Ayırt etme & & & & 1 & $0.63^{* *}$ \\
\hline Toplam & & & & & 1 \\
\hline
\end{tabular}

Tablo 6'da görüldüğü gibi Okul Öncesi İşitsel İşlemleme Testi alt boyutları arasında ve toplam testle pozitif yönde anlamlı bir ilişki bulunmuştur. Elde edilen sonuçlar İ̧̧TE’nin yapı geçerliliğine ilişkin kanıt olarak gösterilebilir.

\section{Üçüncü Aşama: Güvenirlik Hesaplamaları}

Güvenilirlik, bireylerin test maddelerine verdikleri tutarlllık olarak tanımlanmaktadır. Testin ölçek istediği özelliği ne derece ölçtüğü ile ilgilidir (Büyüköztürk, 2016; DeVellis, 2014; Sönmez ve Alacapinar, 2017).

\section{İ̧ Tutarlı11k Güvenilirliği}

Yapılan faktör analizleri sonucunda 21 madde ile son hali verilen ISSTE'nin alt boyutları ve tamamına ilişkin Cronbach alpha güvenilirlik analizleri Tablo 7'de sunulmuştur.

Tablo 7. İŞTE Güvenilirlik İstatistiği

\begin{tabular}{lc}
\hline Faktör & Cronbach’s Alpha \\
\hline Faktör 1: Ses Bilgisel Farkındalık: Aynı Sesle Başlayanlar & 0.84 \\
Faktör 2: Ses Bilgisel Farkındalık: Aynı Sesle Bitenler & 0.86 \\
Faktör 3: Kısa Süreli İşitsel Bellek & 0.94 \\
Faktör 4: İşsitsel Ayırt Etme & 0.78 \\
İ̧STE & 0.88 \\
\hline
\end{tabular}

Tablo 7'de görüldüğü gibi Cronbach Alpha değeri Faktör 1 için 0.84; Faktör 2 için 0.86; Faktör 3 için 0.94; Faktör 4 için 0.78 ve testin tamamı için ,88 olarak hesaplanmıştır. Cronbach Alpha değerinin 0.70’in üzerinde olmasının yeterli olduğu belirtilmektedir (Büyüköztürk, Kılıç Çakmak, Akgün, Karadeniz ve Demirel, 2016). Bu durum testin güvenilirliğinin yüksek olduğunu göstermektedir. 
Tablo 8. İŞTE Madde-Kalan ve Madde-Toplam Korelasyonları

\begin{tabular}{|c|c|c|}
\hline & $\begin{array}{l}\text { Madde- kalan } \\
\text { korelasyonu }\end{array}$ & $\begin{array}{l}\text { Madde-toplam } \\
\text { korelasyonu }\end{array}$ \\
\hline "e" sesi ile başlayan kelimeler & 0.46 & 0.50 \\
\hline “i” sesi ile başlayan kelimeler & 0.46 & 0.53 \\
\hline "k" sesi ile başlayan kelimeler & 0.56 & 0.61 \\
\hline "m" sesi ile başlayan kelimeler & 0.66 & 0.70 \\
\hline "ç" sesi ile başlayan kelimeler & 0.68 & 0.71 \\
\hline "f" sesi ile başlayan kelimeler & 0.66 & 0.71 \\
\hline "e" sesi ile biten kelimeler & 0.53 & 0.59 \\
\hline "i" sesi ile biten kelimeler & 0.55 & 0.61 \\
\hline "k" sesi ile biten kelimeler & 0.63 & 0.68 \\
\hline "m" sesi ile biten kelimeler & 0.68 & 0.73 \\
\hline "ç" sesi ile biten kelimeler & 0.72 & 0.76 \\
\hline "f" sesi ile biten kelimeler & 0.70 & 0.74 \\
\hline Rakam dizisini sıralı söyleme & 0.36 & 0.41 \\
\hline Rakam dizisini tersten sıralı söyleme & 0.56 & 0.59 \\
\hline Kelime dizisini sıralı söyleme & 0.42 & 0.47 \\
\hline Metin hatırlama & 0.44 & 0.54 \\
\hline Kelime dizisi tekrarlama & 0.29 & 0.37 \\
\hline Söyleneni sıra ile yapma & 0.36 & 0.39 \\
\hline Çevresel sesleri tanıma & 0.22 & 0.29 \\
\hline Sesin yerini/yönünü tahmin etme & 0.35 & 0.39 \\
\hline Aynı kelime çiftlerini fark etme & 0.27 & 0.42 \\
\hline
\end{tabular}

Tablo 8.'de her bir madde kalan ve madde toplam puan korelasyonu hesaplamalarında 21 maddenin de korelasyonunun $\mathrm{p}<0.01$ düzeyinde anlamlı oldukları görülmüştür.

Tablo 9. İSTTE Ayırt Edicilik Hesaplamaları

\begin{tabular}{llllllll}
\hline & Grup & $\mathrm{N}$ & $\overline{\mathrm{x}}$ & $\mathrm{SS}$ & $\mathrm{Sd}$ & $\mathrm{t}$ & $\mathrm{p}$ \\
\hline $\begin{array}{l}\text { “e” sesi ile başlayan } \\
\text { kelimeler }\end{array}$ & Alt Grup & 136 & 6.76 & 2.19 & 270 & -11.44 & 0.00 \\
& Üst Grup & 136 & 9.32 & 1.40 & & & \\
\hline $\begin{array}{l}\text { “i” sesi ile başlayan } \\
\text { kelimeler }\end{array}$ & Alt Grup & 136 & 6.40 & 2.13 & 270 & -14.96 & 0.00 \\
\hline "̈ks Gesi ile başlayan & Alt Grup & 136 & 9.39 &, 92 & & & \\
kelimeler & Üst Grup & 136 & 5.07 & 3.41 & 270 & -14.01 & 0.00 \\
\hline “m” sesi ile başlayan & Alt Grup & 136 & 4.20 & 3.39 & 270 & -16.39 & 0.00 \\
kelimeler & Üst Grup & 136 & 9.27 & 1.21 & & & \\
\hline
\end{tabular}


Tablo 9. İŞTE Ayırt Edicilik Hesaplamaları-devamı

\begin{tabular}{|c|c|c|c|c|c|c|c|}
\hline & Grup & $\mathrm{N}$ & $\bar{x}$ & SS & $\mathrm{Sd}$ & $\mathrm{t}$ & $\mathrm{p}$ \\
\hline "ç" sesi ile başlayan & Alt Grup & 136 & 3.11 & 3.31 & 270 & -20.77 & 0.00 \\
\hline kelimeler & Üst Grup & 136 & 9.40 & 1.20 & & & \\
\hline "f" sesi ile başlayan & Alt Grup & 136 & 2.77 & 3.12 & 270 & -20.64 & 0.00 \\
\hline kelimeler & Üst Grup & 136 & 8.78 & 1.33 & & & \\
\hline "e" sesi ile biten & Alt Grup & 136 & 4.03 & 3.07 & 270 & -13.07 & 0.00 \\
\hline kelimeler & Üst Grup & 136 & 8.11 & 1.94 & & & \\
\hline "i" sesi ile biten & Alt Grup & 136 & 4.27 & 3.21 & 270 & -13.74 & 0.00 \\
\hline kelimeler & Üst Grup & 136 & 8.50 & 1.59 & & & \\
\hline "k" sesi ile biten & Alt Grup & 136 & 2.80 & 2.97 & 270 & -18.19 & 0.00 \\
\hline kelimeler & Üst Grup & 136 & 8.25 & 1.83 & & & \\
\hline "m" sesi ile biten & Alt Grup & 136 & 2.18 & 2.70 & 270 & -20.50 & 0.00 \\
\hline kelimeler & Üst Grup & 136 & 8.11 & 2.01 & & & \\
\hline "ç" sesi ile biten & Alt Grup & 136 & 2.37 & 2.70 & 270 & -25.3 & 0.00 \\
\hline kelimeler & Üst Grup & 136 & 8.74 & 1.49 & & & \\
\hline "f' sesi ile biten & Alt Grup & 136 & 2.10 & 2.68 & 270 & -24.88 & 0.00 \\
\hline kelimeler & Üst Grup & 136 & 8.48 & 1.32 & & & \\
\hline \multirow{2}{*}{$\begin{array}{l}\text { Rakam dizisini sıralı } \\
\text { söyleme }\end{array}$} & Alt Grup & 136 & 3.90 & 2.25 & 270 & -8.93 & 0.00 \\
\hline & Üst Grup & 136 & 6.18 & 1.94 & & & \\
\hline \multirow{2}{*}{$\begin{array}{l}\text { Rakam dizisini tersten } \\
\text { söyleme }\end{array}$} & Alt Grup & 136 &, 73 & 1.13 & 270 & -14.49 & 0.00 \\
\hline & Üst Grup & 136 & 3.00 & 1.43 & & & \\
\hline \multirow{2}{*}{$\begin{array}{l}\text { Kelime dizisini siralı } \\
\text { söyleme }\end{array}$} & Alt Grup & 136 & 3.43 & 2.47 & 270 & -10.03 & 0.00 \\
\hline & Üst Grup & 136 & 6.32 & 2.27 & & & \\
\hline \multirow{2}{*}{ Metin hatırlama } & Alt Grup & 136 & 7.42 & 4.84 & 270 & -13.06 & 0.00 \\
\hline & Üst Grup & 136 & 13.79 & 2.98 & & & \\
\hline \multirow{2}{*}{$\begin{array}{l}\text { Kelime dizisi } \\
\text { tekrarlama }\end{array}$} & Alt Grup & 136 & 7.54 & 3.78 & 270 & -8.52 & 0.00 \\
\hline & Üst Grup & 136 & 10.67 & 2.01 & & & \\
\hline \multirow{2}{*}{$\begin{array}{l}\text { Söyleneni s1ra ile } \\
\text { yapma }\end{array}$} & Alt Grup & 136 & 3.00 & 2.57 & 270 & -6.99 & 0.00 \\
\hline & Üst Grup & 136 & 5.02 & 2.18 & & & \\
\hline \multirow{2}{*}{ Çevresel sesleri tanıma } & Alt Grup & 136 & 7.74 & 2.87 & 270 & -5.15 & 0.00 \\
\hline & Üst Grup & 136 & 9.34 & 2.18 & & & \\
\hline \multirow{2}{*}{$\begin{array}{l}\text { Sesin yerini/ yönünü } \\
\text { tahmin etme }\end{array}$} & Alt Grup & 136 & 4.68 & 1.75 & 270 & -8.49 & 0.00 \\
\hline & Üst Grup & 136 & 6.44 & 1.67 & & & \\
\hline \multirow{2}{*}{$\begin{array}{l}\text { Aynı kelime çiftlerini } \\
\text { fark etme }\end{array}$} & Alt Grup & 136 & 27.46 & 7.60 & 270 & -8.31 & 0.00 \\
\hline & Üst Grup & 136 & 27.30 & 2.98 & & & \\
\hline
\end{tabular}

Tablo 9'da 21 maddenin ayırt edicilik güçleri saptanmıştır. Testten elde edilen ham puanlar büyükten küçüğe doğru sıralanarak alt ve üst \%27’lik dilime yer alan grupların puan ortalamalarının t değerleri hesaplanarak madde ayırt edicilik güçleri elde edilmiştir. İŞTE puanları alt ve üst grupları arasında yapılan $\mathrm{t}$ testinde bütün maddeler $\mathrm{p}<0.01$ düzeyinde anlamlı bulunmuştur.

Cronbach Alpha güvenilirliği ve madde analizleri işlemlerine ilişkin elde edilen sonuçlar İ̧STE’nin iç tutarlılık güvenilirliğine kanıt olarak gösterilebilir. 


\section{Zamana Karşı Değişmezlik Güvenilirliği}

Bu güvenilirlik analizi ile hazırlanan ölçeğin, uygulamadan uygulamaya tutarlı sonuçlar verebilme, zamana göre değişmezlik gösterebilme gücü incelenir (Çam ve Arabac1, 2010). İŞTE, 33 kişilik bir örneklem grubuna uygulanmış, 5 hafta sonra aynı gruba tekrar uygulama yapılmıştır. Tavşancıl (2002) iki ölçüm arasında dört-altı haftalık bir sürenin yeterli olacağını belirtmektedir.

Tablo 10. IŞSTE Kararlllık Hesaplamaları

\begin{tabular}{|c|c|c|c|c|c|c|c|}
\hline Faktörler & Grup & $\mathrm{N}$ & $\bar{x}$ & SS & $\mathrm{Sd}$ & $\mathrm{t}$ & $\mathrm{p}$ \\
\hline \multirow{2}{*}{$\begin{array}{l}\text { Faktör 1: Ses Bilgisel } \\
\text { Farkındalık Aynı } \\
\text { Sesle Başlayanlar }\end{array}$} & Test & 33 & 33.63 & 5.75 & \multirow[t]{2}{*}{32} & \multirow[t]{2}{*}{-0.47} & \multirow[t]{2}{*}{0.64} \\
\hline & Tekrar Test & 33 & 39.75 & 5.69 & & & \\
\hline \multirow{2}{*}{$\begin{array}{l}\text { Faktör 2: Ses Bilgisel } \\
\text { Farkındalık Aynı } \\
\text { Sesle Bitenler }\end{array}$} & Test & 33 & 47.87 & 10.55 & \multirow[t]{2}{*}{32} & \multirow[t]{2}{*}{1.01} & \multirow[t]{2}{*}{0.32} \\
\hline & Tekrar Test & 33 & 47.12 & 10.91 & & & \\
\hline \multirow{2}{*}{$\begin{array}{l}\text { Faktör 3: Kısa Süreli } \\
\text { İşitsel Bellek }\end{array}$} & Test & 33 & 36.48 & 13.70 & \multirow[t]{2}{*}{32} & \multirow[t]{2}{*}{-0.39} & \multirow[t]{2}{*}{0.70} \\
\hline & Tekrar Test & 33 & 36.75 & 14.30 & & & \\
\hline \multirow{2}{*}{$\begin{array}{l}\text { Faktör 4: İşitsel Ayırt } \\
\text { etme }\end{array}$} & Test & 33 & 37.15 & 9.98 & \multirow[t]{2}{*}{32} & \multirow[t]{2}{*}{-10.46} & \multirow[t]{2}{*}{0.15} \\
\hline & Tekrar Test & 33 & 37.67 & 9.28 & & & \\
\hline \multirow{2}{*}{ İSTE } & Test & 33 & 161.15 & 27.93 & \multirow[t]{2}{*}{32} & \multirow[t]{2}{*}{3.03} & \multirow[t]{2}{*}{0.76} \\
\hline & Tekrar Test & 33 & 161.30 & 28.37 & & & \\
\hline
\end{tabular}

Tablo 10 'da 5 hafta arayla yapılan iki ölçüm puanları arasında farklılık eşleştirilmiş grup farkları testi ile incelenmiş, anlamlı bir farklılık bulunamamıştır.

Tablo 11. İ̧̧TE Zamana Karşı Değişmezlik Katsayısı Hesaplamaları

\begin{tabular}{llll}
\hline Faktörler & $\mathrm{N}$ & $\mathrm{r}$ & $\mathrm{p}$ \\
\hline Faktör 1: Ses Bilgisel Farkındalık: Aynı Sesle Başlayanlar & 33 & 0.97 & 0.00 \\
Faktör 2: Ses Bilgisel Farkındalık: Aynı Sesle Bitenler & 33 & 0.92 & 0.00 \\
Faktör 3: Kısa Süreli İşitsel Bellek & 33 & 0.96 & 0.00 \\
Faktör 4: İşitsel Ayırt Etme & 33 & 0.98 & 0.00 \\
IŞTE & 33 & 0.99 & 0.00 \\
\hline
\end{tabular}

Tablo 11'de 5 hafta arayla yapılan iki ölçüm arasındaki korelasyona bakılarak, güvenirlilik katsayıları belirlenmiştir. Şencan (2005) bu korelasyon katsayısının en az 0.80 olması gerektiğini belirtmektedir. İŞTE zamana karşı değişmezlik katsayıları 0.80’in üzerindedir.

İ̧TE'nin 5 hafta arayla 33 kişilik gruba uygulanmasından elde edilen puanlarla yapılan eşleştirilmiş grup farkları testi ve korelasyon katsayılarından elde edilen zamana karşı değişmezlik katsayısı ile ilgili bulgular zamana karşı değişmezlik güvenilirliğine kanıt olarak gösterilebilir.

\section{Benzer Ölçek Güvenilirliği}

Bir testin puanlarının testin ölçtüğü özelliklerle ilgili olduğu düşünülen bir başka ölçme sonuçları ile korelasyonu benzer ölçek güvenilirliğini göstermektedir (Büyüköztürk, Çakmak, Akgün, Karadeniz, Demirel, 2016). IŞSTE’nin benzer ölçek güvenilirliğini sınamak amaciyla Erken 
Okuryazarlık Becerilerini Değerlendirme Aracı (EOBDA)-Ses Bilgisel Farkındalık Becerilerini Değerlendirme Alt Testi ve Marmara İlköğretime Hazır Oluş Ölçeği (MİHÖ)-Uygulama Formu: Ses Çalışmaları Alt Ölçeği ile 30 kişilik bir gruba uygulanmıştır. Elde edilen puanlar İŞTE Aynı Sesle Başlayan Kelimeler ve Aynı Sesle Biten Kelimeler Alt Testleri (İSTE1-2) puanları ve toplam puanlarla karşılaştırılmıştır.

Tablo 12. İşTE Benzer Ölçek Karşılaştırmaları

\begin{tabular}{llllll}
\hline Grup & $\mathrm{N}$ & $\overline{\mathrm{x}}$ & $\mathrm{SS}$ & $\mathrm{R}$ & $\mathrm{p}$ \\
\hline ISSTE Toplam & 30 & 149.17 & 43.62 & 0.79 & 0.00 \\
EOBDA-Ses & 30 & 30.97 & 13.34 & & \\
\hline ISŞTE 1-2 & 30 & 82.40 & 33.27 & 0.80 & 0.00 \\
EOBDA-Ses & 30 & 90.97 & 13.37 & & \\
\hline İȘTE Toplam & 30 & 149.17 & 43.62 & 0.81 & 0.00 \\
MİHÖ-Ses & 30 & 4.07 & 2.39 & & \\
\hline İŞTE 1-2 & 30 & 82.40 & 33.27 & 0.88 & 0.00 \\
MİHÖ-Ses & 30 & 4.06 & 2.39 & & \\
\hline
\end{tabular}

Tablo 12'de İşTE Aynı Sesle Başlayan Kelimeler ve Aynı Sesle Biten Kelimeler Alt Testleri (IŞTE12) puanları ve toplam puanları ile Erken Okuryazarlık Becerilerini Değerlendirme Aracı (EOBDA)Ses Bilgisel Farkındalık Becerilerini Değerlendirme Alt Testi ve Marmara İlköğretime Hazır Oluş Ölçeği (MİHÖ)-Uygulama Formu: Ses Çalışmaları Alt Ölçeği puanları arasındaki korelasyon analizi görülmektedir. İŞTE Toplam puanları ile EOBDA-Ses arasında $\mathrm{p}<0.01$ düzeyinde $(\mathrm{r}=0.79)$; İSTTE Aynı Sesle Başlayan Kelimeler ve Aynı Sesle Biten Kelimeler Alt Testleri (İŞTE1-2) puanları ile EOBDA-Ses arasında $\mathrm{p}<0.01$ düzeyinde $(\mathrm{r}=0.80)$; IŞTE Toplam puanları ile MİHÖ-Ses arasında $\mathrm{p}<0.01$ düzeyinde ( $\mathrm{r}=0.81)$; İ̧STE Aynı Sesle Başlayan Kelimeler ve Aynı Sesle Biten Kelimeler Alt Testleri (İŞTE1-2) puanları ile MİHÖ-Ses arasında $\mathrm{p}<0.01$ düzeyinde $(\mathrm{r}=0.88$ ) anlamlı bir korelasyon olduğu görülmektedir.

Ayrıca İŞTE’nin benzer ölçek güvenilirliği Selçuk İşitsel Muhakeme ve İşlem Becerileri Testi (SIMIBT) ile de sınanmıştır. 30 kişilik bir guruba her iki test ve alt ölçekleri uygulanmış ve puanları karşılaştırılmıştır.

Tablo 13. İŞTE - SIMIBTT Benzer Ölçek Karşılaştırmaları

\begin{tabular}{lcccccc}
\hline & & $\begin{array}{l}\text { Ses Bilgisel } \\
\text { Farkındalı: } \\
\text { Aynı Sesle } \\
\text { Başlayanlar }\end{array}$ & $\begin{array}{l}\text { Ses Bilgisel } \\
\text { Farkındalı: } \\
\text { Aynı Sesle } \\
\text { Bitenler }\end{array}$ & $\begin{array}{l}\text { Kısa Süreli } \\
\text { İşitsel Bellek }\end{array}$ & $\begin{array}{l}\text { İşitsel Ayırt } \\
\text { Etme }\end{array}$ & İ̧̧TE \\
\hline SİMiBT & $\mathrm{r}$ & 0.56 & 0.74 & 0.64 & 0.50 & 0.85 \\
& $\mathrm{p}$ & 0.00 & 0.00 & 0.00 & 0.01 & 0.00 \\
& $\mathrm{~N}$ & 30 & 30 & 30 & 30 & 30 \\
\hline
\end{tabular}


Tablo 13'de ISSTE alt testleri ve SIMİBT toplam puanları arasındaki korelasyon analizi görülmektedir. İSTE Ses Bilgisel Farkındalık: Aynı Sesle Başlayanlar Alt Testi ile SİMIBTT arasında $\mathrm{p}<0.01$ düzeyinde $(\mathrm{r}=0.56)$ düzeyinde anlamlı bir korelasyon olduğu görülmektedir. İŞTE Ses Bilgisel Farkındalık: Aynı Sesle Bitenler Alt Testi ile SIMİBT arasında $\mathrm{p}<0.01$ düzeyinde $(\mathrm{r}=0.74)$ düzeyinde anlamlı bir korelasyon olduğu görülmektedir. İŞTE Kısa Süreli İşitsel Bellek Alt Testi ile SİMIBT arasında $\mathrm{p}<0.01$ düzeyinde $(\mathrm{r}=0.64)$ düzeyinde anlamlı bir korelasyon olduğu görülmektedir. İŞTE İşitsel Ayırt Etme Alt Testi ile SIMİBT $\mathrm{p}<0.01$ düzeyinde $(\mathrm{r}=0.85)$ düzeyinde anlamlı bir korelasyon olduğu görülmektedir. İŞTE ile SİMIBT arasında $\mathrm{p}<0.01$ düzeyinde $(\mathrm{r}=0.50)$ düzeyinde anlamlı bir korelasyon olduğu görülmektedir.

Elde edilen bulgular benzer ölçek güvenilirliğine kanıt gösterilebilir.

\section{SONUÇ ve TARTIŞMA}

48-72 aylık işitme engeli olmayan çocuklar için geliştirilen Okul Öncesi İşitsel İşlemleme Testi (İŞTE)'nin geçerlik güvenilirlik çalışmasının yapılmasını amaçlayan çalışmaya sonuç ve tartışma bu bölümde sunulmuştur.

Öncelikli olarak, Okul Öncesi İşitsel İsslemleme Testi (ISSTE)'nin yüzey ve kapsam geçerliliği saptanmıştır. İşitsel farkındalık (seslerin fark edilmesi), işitsel ayırım (sesleri arasındaki farklılığı ayırt etme), işitsel lokalizasyon (seslerin yerini belirleme), işitsel bellek (zihinde depolama ve geri çağırma), işitsel ardışıklık (uyarıları belli bir düzen içinde hatırlayabilme), ses bilgisel farkındalık (sesli ve sessiz fonem kullanımı); işitsel dikkat (hedef sesleri fark etme) alt boyutlarında 22 liste şeklinde tasarlanmıştır. Testin yüzey geçerliliği araştırmacı ve 7 alan uzmanından alınan görüşlerle değerlendirilmiştir. Alan uzmanlarından alınan görüşler doğrultusunda İŞTE içeriğindeki kapsam geçerlik oranı> kapsam geçerlik indeksi oranını sağlayan 22 listenin kapsam geçerliği istatistiksel olarak anlamlı bulunmuştur. Ardından, İŞTE, 48-60 aylık 2011 doğumlu 100 kız, 101 erkek çocuk; 61-72 aylık 2010 doğumlu 151 kı, 150 erkek çocuk olmak üzere 48-72 aylık 502 çocuğa uygulanmıştır (Tablo 1).

Açımlayıcı faktör analizi işlemlerine geçebilmek için örneklem büyüklügüünün uygunluğu KaiserMeyer-Olkin (KMO) Testi ile 0.88 olarak tespit edilmiştir (Tablo 2) ve bu değer ile örneklem büyüklügünün “iyi” olduğu sonucuna varılmıştır. Ayrıca Bartlett Küresellik testi sonuçları i ki-kare değerinin $\left(\chi^{2}{ }_{(231)}=6905.36 ; \mathrm{p}<0.01\right)$ anlamlı olduğunu göstermektedir (Tablo 2). Cronbach Alpha değeri 0.78 olduğundan verilerinin güvenirliğinin yüksek olduğu söylenebilir (Büyüköztürk, 2010).

ISSTE faktör desenini ortaya koymak amacıyla faktörleştirme yöntemi olarak temel bileşenler analizi; döndürme yöntemi olarak da dik döndürme yöntemlerinden maksimum değişkenlik (varimax) 
seçilmiştir (Şencan 2005. Tavşancıl, 2002). Yapılan faktör analizi sonrasında listelerin öz değeri 1 ve 1'in üzerinde 5 grupta kümelendiği görülmüştür (Tablo 3). Toplam varyansın \%33.04’ünü birinci, \%14.84’ünü ikinci, \%8.48’ini üçüncü, \%6.15’ini dördüncü, \%5.33’ünü beşinci bileşenin açıkladığı, toplam varyansa ise \%67.84 oranında katkı sağladığı bulunmuş, beşinci bileşenin tek listeden oluşması nedeniyle testten çıkartılarak işlemler tekrarlanmıştır.

Tekrarlanan açımlayıcı faktör analizi sonunda İŞTE'yi oluşturan 21 madde için öz değeri 1'in üzerinde 4 bileşen bulunmuştur (Tablo 4). Toplam varyansın \%33.49’unu birinci, \%15.30’unu ikinci, \%8.67'sini üçüncü, \%6.38'ini dördüncü bileşenin açıklamakta, toplam varyansa ise \%64.84 oranında katkı sağlamaktadır. İŞTE'deki dört faktörün öz değerleri sırasıyla faktör 1 için 7.24; faktör 2 için 3.21; faktör 3 için 1.83 ve faktör 4 için 1.34'tür. Öz değeri 1 ve 1 den fazla $(\lambda \geq 1)$ olan 4 faktör olduğundan bu dört faktör seçilmiştir. Literatür taramasından elde edilen bilgiler 1şığında belirlenen 4 faktör yeniden isimlendirilmiştir (Faktör 1: Ses Bilgisel Farkındalık:Aynı Sesle Başlayanlar, Faktör 2: Ses Bilgisel Farkındalık:Aynı Sesle Bitenler; Faktör 3:Kısa Süreli İşitsel Bellek, Faktör 4: İssitsel Ayırt Etme).

İç tutarlılık güvenirliğinin sınanmasında, Cronbach Alpha değeri Faktör 1 için 0.84; Faktör 2 için 0.86; Faktör 3 için 0.94; Faktör 4 için 0.78 ve testin tamamı için 0.88 olarak hesaplanmıştır (Tablo 7). Değerler testin güvenilirliğinin yüksek olduğunu göstermektedir. (Büyüköztürk, Kılıç Çakmak, Akgün, Karadeniz ve Demirel, 2016).

İSTE madde kalan ve madde toplam puan korelasyonu hesaplamalarında 21 maddenin de korelasyonunun $\mathrm{p}<0.01$ düzeyinde anlamlı oldukları görülmüş (Tablo 8); alt ve üst \%27’lik dilimlerde yer alan puan grupları arasında yapılan $\mathrm{t}$ testinde bütün maddeler $\mathrm{p}<0.01$ düzeyinde anlamlı bulunmuştur (Tablo 9).

Zamana göre değişmezlik güvenirliğinin sınanması için IŞTE 5 hafta ara ile 33 öğrencilik bir gruba uygulanmış ve iki ölçüm puanları arasında farklılık eşleştirilmiş grup farkları testi ile incelenmiş, anlamlı bir farklılık bulunamamış (Tablo 10); ayrıca zamana göre değişmezlik katsayısı hesaplamaları için iki ölçüm arasındaki korelasyona bakılarak belirlenen güvenirlik katsayıları da 0.80’in üzerinde bulunmuştur (Tablo 11).

Testin benzer ölçek güvenirliği için Erken Okuryazarlık Becerilerini Değerlendirme Aracı (EOBDA)-Ses Bilgisel Farkındalık Becerilerini Değerlendirme Alt Testi ve Marmara İlköğretime Hazır Oluş Ölçeği (MİHÖ)-Uygulama Formu: Ses Çalışmaları Alt Ölçeği ile 30 kişilik bir gruba uygulanmıştır. Elde edilen puanlar İŞTE Aynı Sesle Başlayan Kelimeler ve Aynı Sesle Biten Kelimeler Alt Testleri (IŞTE1-2) puanları ve toplam puanlarla karşılaştırılmıştır. İŞTE Toplam puanları ile EOBDA-Ses arasında $\mathrm{p}<0.01$ düzeyinde $(\mathrm{r}=0.79)$; İŞTE Aynı Sesle Başlayan Kelimeler 
ve Aynı Sesle Biten Kelimeler Alt Testleri (ISSTE1-2) puanları ile EOBDA-Ses arasında p $<0.01$ düzeyinde $(\mathrm{r}=0.80)$; İSTE Toplam puanları ile MİHÖ-Ses arasında $\mathrm{p}<0.01$ düzeyinde $(\mathrm{r}=0.81)$; ISSTE Aynı Sesle Başlayan Kelimeler ve Aynı Sesle Biten Kelimeler Alt Testleri (ISSTE1-2) puanları ile MİHÖ-Ses arasında $\mathrm{p}<0.01$ düzeyinde $(\mathrm{r}=0.88)$ anlamlı bir korelasyon olduğu bulunmuştur (Tablo 12).

Elde edilen bulgular Okul Öncesi İşitsel İşlemleme Testi’nin geçerlik ve güvenirliğine kanıt gösterilebilecek niteliktedir. İŞTE 4 faktörlü bir yapıdan oluşmaktadır.

(1) Ses Bilgisel Farkındalık: Aynı Sesle Başlayanlar Alt Testi aritmetik ortalaması 37.63. standart sapmas1 12.74 'dür. Alt Testten alınan minimum puan 11. 00 maksimum puan 60.00'dır. Cronbach Alpha güvenirlik katsayısı 0.84’tür.

(2) Ses Bilgisel Farkındalık: Aynı Sesle Bitenler Alt Testi aritmetik ortalaması 43.76. standart sapmas1 17.01. Alt Testten alınan minimum puan 0. 00 maksimum puan 60.00'dır. Cronbach Alpha güvenirlik katsayısı 0.86'dır.

(3) Kısa Süreli İşitsel Belek Alt Testi aritmetik ortalaması 33.44. standart sapması 11.28'dir. Alt Testten alınan minimum puan 0.00 maksimum puan 53.00'dır. Cronbach Alpha güvenirlik katsayısı 0.94'tür.

(4) İşitsel Ayırt Etme Alt Testi aritmetik ortalamas1 34.25. standart sapmas1 7.28'dir. Alt Testten alınan minimum puan 0.00 maksimum puan 51.00'dır. Cronbach Alpha güvenirlik katsayısı 0.78 'dir. İŞTE aritmetik ortalaması 148.42. standart sapması 1.58 'dir. Testten alınan minimum puan 60.00 maksimum puan 215.00'dır. Cronbach Alpha güvenirlik katsayıs1 0.88'dir.

Çevremizi anlamak ve yorumlamak duyusal verilerin bir dizi işlemden geçirilerek algılanmasını gerektiren aktif bir süreçtir (Bulduk, 2014; May, 2007). Çevresel uyaranları almak ve bu uyaranın enerjisini elektrokimyasal bir potansiyele dönüştürmek; ardından bu bilgiyi merkezi sinir sistemine taşımak ve bu uyaranı analiz ederek işlemek temel duyusal işlevlerdendir (Küçükoğlu ve Tunçeli, 2019). Sesleri yeterli ve doğru şekilde işitebilen, bu seslerin benzerlik ya da farklılıklarını fark edebilen çocukların okumayı öğrenmesi daha kolay olacaktır (Oktay, 2010). Dinleme, anlama ve kavrama becerileri, okuduğunu anlama becerilerinin ön koşullarındandır ve bu nedenle erken okuryazarlık becerileri açıcından önemlidir (Kuru ve Koç Tüylü, 2019). Bu nedenle çocukların erken okuma becerileri ve hazır bulunuşlukları değerlendirilirken işitsel işlemleme becerilerinin de değerlendirilmesi önemlidir. 
Okul öncesi eğitim programında (MEB, 2013), okuma ve yazı farkındalı̆̆1 ve ses bilgisel farkındalık becerilerinin gelişimin desteklemek üzere kazanım ve göstergeleri yer almaktadır. Bu beceriler çocukların dil gelişimleri ve okumaya hazırlık çalışmaları için önemli bir temel oluşturmaktadır. Konu ile ilgili alan yazında yer alan çalışmalar, işitsel işlemleme becerilerinin ve alt boyutlarının desteklenmesinin önemini ve eğitim ortamındaki yansımalarını ortaya koymaktadır.

Vanvooren, Poelmans, De Vos, Ghesquière ve Wouters (2017) 87 anasınıfı öğrencisi ile yaptıkları boylamsal çalışmada anaokulunda bu becerilere ilişkin gösterdikleri performans ile ses bilgisel farkındalık ve okur yazarlık arasında ilişki olduğunu belirtmektedir. White-Schwoch, Carr, Thompson, Anderson, Nicol, Bradlow, Zecker ve Kraus (2015) 3-14 yaşlarındaki 112 çocukla yaptıkları çalışmada ünsüz seslerin işlenmesinin erken okuma becerilerinde temel olduğunu ortaya koymuştur. Otaiba ve diğerleri (2008), 286 öğrencinin 17 öğretmeni ile yaptıkları ses bilgisel farkındalık eğitimi ile ilgili olarak 1 eğitim yılı boyunca hergün uygulamalar yapmış ve sonuçları değerlendirmişlerdir. Çalışmanın en çarpıcı bulgularından biri, ses bilgisel farkındalık becerileri açısından bireyselleştirilmiş uygulamaların daha etkili sonuçlar ortaya koymasıdır. Erbay (2013), 204 çocukla yaptığı çalışmada çocukların dikkat toplam becerileri ve genel bilgi, eşleştirme, cümleler ve kelime anlama becerileri ile işitsel muhakeme ve işlemleme becerileri arasında pozitif yönlü anlamlı bir ilişki olduğunu tespit etmiştir. Niemitalo-Haapola, Haapala, Kujala, Raappana, Kujala ve Jansson-Verkasalo (2017), 2-4 yaş arasında 14 çocukla yaptıkları çalışmada merkezi işitsel işlemede olaya bağlı potansiyeller tarafından sıralanan gelişimsel ve gürültü kaynaklı değişiklikler incelenmiştir. Çalışma sonuçları, gürültünün seslerin kodlanmasını ve yankı belleğini bozduğunu, tüm yaşlarda işitsel ayırt etmeyi bozduğunu ve büyük çocuklar gibi küçük çocukların da gürültünün etkilerine karşı savunmasız olduğunu ortaya koymaktadır. Thompson, Carr, White-Schwoch, OttoMeyer ve Kraus (2017) 3-5 yaş aralığındaki çocukların öğrenme ortamındaki gürültüden etkilenmeden konuşulanları algılamasına yönelik boylamsal bir çalışma yapmışlardır. Çalışmada 59 çocuğun 12 ay süreyle gürültülü ortamda sözcük algılaması, bilişsel yetenekleri ve konuşmaya verdikleri sinirsel tepkileri incelenmiştir. Sonuçlar konuşmacıların tanımlanmasında ve işitsel sahne analizinde merkezi bir rol oynadığı bilinen akustik bir işaret olan temel frekansın işlenmesinde, gürültülü ortamda sözcük alg1sı ile paralel değişiklikler olduğunu ortaya koymuştur. Gürültülü ortamda sözcük algılanması kısa süreli hafıza ile değil temel frekanslarn işlenmesi ile ilişkilendirilmiş; daha büyük çocuklar ve yetişkinlerde tespit edilen bu ilişkinin erken çocuklukta da görüldüğü vurgulanmaktadır. Bilir, Bal ve Artan (1993), işitme engelli 5 çocukla yaptıkları deneysel çalışmada öncelikli olarak odyometrik ölçümler yapılmıştır. Çocukların işitme derecelerine uygun frekanstaki müzik aletleri kullanılarak uygulamalar yapılmış ve ses ile kaynağı eşleştirme, ses kaynağını isimlendirebilme, ses kaynağının ismini modeli taklit ederek tekrarlayabilme, işittikleri sese ait sözel 
ifade kullanabilme çalışmalarında yaptıkları karşılaştırmalarda son test puanlarının başarı yüzdelerinin ön test puanlarından yüksek olduğunu saptamışlardır.

Alan yazında işitsel alg1 ve işitsel işlemleme becerilerini ölçmeye yönelik test materyalleri bulunmaktadır. Erbay (2013), Garder tarafindan geliştirilen İşitsel Muhakeme ve İşlem Becerileri Testi (Test of Auditory Reasoning and Processing Skills-TARPS), ülkemize uyarlanmıştır (IMIBT). $\mathrm{Bu}$ testin alt boyutları genel bilgi, matematiksel muhakeme, sözel anlamsızlıklar, sebep bulma, analojik tamamlamalar, anlama, doğrusal yönlendirme, benzersizlikler becerilerini içermektedir.

Martin ve Brownell (2005)'in, İşitsel İşlemleme Becerileri Testi (Test of Auditory Processing SkillsTAPS) kelime ayırt etme, ses ayırt etme, fonolojik kaynaştırma, rakam sıralı hatırlama, tersten rakam sırası hatırlama, kelime hatırlama, cümle hatırlama, işitsel anlama, işitsel muhakeme alt boyutlarından oluşmaktadır.

Karaman (2013) tarafından geliştirilen Erken Okuryazarlık Becerilerini Değerlendirme Aracı içerisinde ses bilgisel farkındalık becerilerini değerlendirme, yazı farkındalığı öyküyü anlama, görselleri eşleştirme ve yazı yazma öncesi becerileri değerlendirme alt testleri yer almaktadır.

Sarı ve Aktan Acar (2013)'ın, geliştirdikleri Erken Çocukluk Dönemi Fonolojik Duyarlılık Ölçeği, iki sözcüğün kafiyeli olup olmadığına karar verebilme, Kelimelerin başlangıç seslerini ayırt edebilme, İstenilen ses ile yeni kelimeler oluşturabilme, Bir grup kelime içinden aynı sesle başlayanları fark edebilme/gruplayabilme, Sesbirimlerini bir araya getirerek oluşan kelimeyi söyleyebilme, Bir kelimeyi hecelere ayırabilme, Bir kelimedeki bir kelimeyi/bir heceyi atarak geriye kalan birimi söyleyebilme, Harfleri tanıma alt boyutlarında 8 faktörlü bir yapıya sahiptir.

Tepeli, Er Şahin ve Erbay (2018) tarafindan geliştirilen Selçuk İşitsel Muhakeme ve İşlem Becerileri Testi (SIMIBT) Genel Bilgi, Aritmetik Muhakeme, Benzerlikler, Sözel Anlamsızlıklar, Analojik Tamamlama ve Nedensel Muhakeme alt testleri ile 6 faktörlü bir yapıya sahiptir.

Alan yazındaki benzer ölçeklerin ortak noktası ses bilgisel farkındalık / fonolojik duyarlılık ile ilgili alt boyutlar içermesidir (Karaman, 2013; Martin ve Brownell, 2005; Sarı ve Aktan Acar , 2013; Tepeli, Er Şahin ve Erbay, 2018). IŞTE bu yapıyla benzer olarak Ses Bilgisel Farkındalık: Aynı Sesle Başlayan Kelimeler, Ses Bilgisel Farkındalık: Aynı Sesle Biten Kelimeler alt boyutlarına sahiptir. Bu boyutlar özellikle erken okuma becerileri açısından önemlidir. Ayrıca ISSTE içerisinde yer alan Kısa Süreli İşitsel Bellek alt boyutu anlama, bellek ve hatırlama içerikli listeleri ile (Erbay, 2013; Martin ve Brownell, 2005; Tepeli, Er Şahin ve Erbay, 2018) sözel uyaranları tanıma, anlama, ayırt etme ve kısa süreli hafızaya alarak tekrar ifade etme becerilerini de değerlendirmektedir. Bu beceriler öğrenme ortamı içerisinde yönergeleri anlama, ayırt etme ve gereğini yerine getirme açısından 
önemlidir. Ayrıca İşitsel Ayırt Etme alt boyutu ile çevresel sesleri tanımak, ayırt etmek ve hedefe odaklanma becerileri açısından önemlidir.

Ölçme araçların geçerlilik ve güvenirliğine ilişkin alan yazında yer alan analiz teknikleri uygulanarak geçerlilik ve güvenirliği test edilen Okul Öncesi İşitsel İşlemleme Test (İŞTE’nin) geçerli ve güvenilir bir ölçme aracı olduğu söylenebilir. 


\section{KAYNAKÇA}

Aamondt, S., \& Wang, S. (2011). Welcome to Your Child's Brain: How the Mind Grows from Conception to College. USA: Bloomsbury.

Akarsu, B. (2017). Modern Ögrretim Teknolojisi ve Materyal Tasarmı. İstanbul: Cinius Yayınları.

American Speech-Language-Hearing Association. (2005). Auditory processing disorders. http:/ / asha.org/policy adresinden 12 Haziran 2015 tarihinde erişilmiştir.

Atlı, S., ve Beyazıt, U. (2015). Bebeklik ve ilk çocukluk döneminde duyusal deneyimler. M. Yıldız B1çakçı içinde, Bebeklik ve İlk Cocukluk Döneminde (0-36 Ay) Gelişim: Duyularn Gelişimi ve Desteklenmesi. Ankara: Eğiten Kitap Yayıncılık.

Barker, M., \& Purdy, S. (2016). An initial investigation into the validity of a computer-based auditory processing assessment (Feather Squadron). International Journal of Audiology, 55, 173 183.

Baş, T., ve Akturan, U. (2017). Sosyal Bilimlerde Bilgisayar Destekli Nitel Araștırma Yöntemleri. Ankara: Seçkin Yayıncılık.

Beaty, J., \& Pratt, I. (2015). Early Literacy in Preschool and Kindergarden: A Multicultural Perspective. USA: Pearson.

Bellis, T. (2002). When The Brain Can't Hear: Unraveling The Mystery of Auditory Processing Disorder. New York: Pocket Books.

Best, J., \& Kahn, J. (2017). Eğitimde Arastırma Yöntemleri. (O. Küksal, Dü.) Konya: Eğitim Yayınevi.

Bilavski, E., Shahar-Nissan, K., Pardo, J., Attias, J., \& Amir, J. (2016). Hearing outcome of infants with congenital cytomegalovirus and hearing impairment. ADC Online First, 1-6.

Bilir, Ş., Bal, S., \& Artan, İ. (1993). Anaokuluna devam eden 5-7 yaş grubundaki ileri derecede işitme özürlü çocukların işitsel alg1 gelişimlerinin incelenmesi. Aile ve Toplum, 1(3), 67-77.

Boets, B., Wouters, J., van Wieringen, A., \& Ghesquire, P. (2007). Auditory processing, speech perception and phonological ability in pre-school children at high-risk for dyslexia: A longitudinal study of the auditory temporal processing theory. Neuropsychologia, 45(8), 16081620.

Bulduk,S. (2014). Duyum ve alg1. Editör:Sevda Bulduk Duyum ve Algı Psikolojisi içinde 1. Bölüm. Ankara: Nobel Tıp Kitapevleri

Büyüköztürk, Ş. (2016). Sosyal Bilimler İ̧in Veri Analiæ̧i El Kİtabı. Ankara: Pegem Akademi Yayınları. 
Büyüköztürk, Ş., Kılıç Çakmak, E., Akgün, Ö. E., Karadeniz, Ş., ve Demirel, F. (2016). Bilimsel Araştırma Yöntemleri. Ankara: Pegem Akademi YAyınları.

Child, D. (2006). The Essentials of Factor Analysis. London: Continuum International Publishing.

Comrey, A., ve Lee, H. (1992). A first course in factor analysis. New Jersey: Lawrence Erlbaum Associates Publishers.

Çam, M.O., ve Baysan-Arabacı, L. (2010). Tutum ölçeği hazırlamada nitel ve nicel adımlar. Hemsirelikte Arama ve Gelistirme Dergisi, 2, 59-71.

Darıca, N., ve Şipal, F. (2011). İsitme Engelli Çocuklarda Gelişim Ve Eğitsel Müdahale. Ankara: Hacettepe Üniversitesi Yayınları.

Dekerle, M., Meunier, F., N'Guyen, M.-A., Gillet-Perret, E., Lassus-Sangosse, D., \& Donnadieu, S. (2018). Central auditory processing development in primary school children. International Journal of Phonetics and Audiology.

DeVellis, R. (2014). Ölçek Gelişstirme Kuram ve Uygulamalar. (T. Totan, Dü.) Ankara: Nobel Akademik Yayincilik.

Erbay, F. (2013). Dikkat toplama ve okuma olgunluğu değişkenlerinin altı yaş çocuklarının işitsel muhakeme ve işlem becerilerini yordama gücü. Kuram ve Uygulamada Eğitim Bilimleri, 13(1), 413-429.

Fraenkel, J., Wallen, N., \& Hyun, H. (2015). How to Design ande Evaluate Research in Education. New York: Mc Graw Hill Education.

Gardner, M. (1993). Test of Auditory Reasoning And Processing Skills Manuel. Novato: Academic Therapy Publication.

Girgin, C., ve Kemaloğlu, Y. (2017). İşitme yetersizliği olan çocuklara yönelik eğitim ortamları ve eğitimlerine kullanılan iletişim yaklaşımları. H. Gürgür, \& P. Şafak içinde, İşitme ve Görme Yetersizliği. Ankara: Pegem Akademi Yayınları.

Gliner, J., Morgan, G., \& Leech, N. (2009). Research Methods in Applied Settings An Integrated Approach To Design And Analysis. London: Routledge.

Guilford, J. (1954). Psycometric Methods. New York: Mc Graw Hill.

İncesulu, A. (2017). İşitme sistemi ve anatomisi. Edt: Zerrin Turan, İsitmenin Doğası ve Yardıma Teknolojiler içinde Bölüm 2. Ankara: Pegem Akademi. 
Karakoç, F., ve Dönmez, L. (2014). Ölçek geliştirme çalışmalarında temel ilkeler. T⿰力p Eğitimi Dünyası(40), 9-18.

Karaman, G. (2013). Erken okuryazarlı becerilerini değerlendirme araci'nun gelistirilmesi geçerlik ve güvenirlik çalşması. Ankara: Gazi Üniversitesi Eğitim Bilimleri Enstitüsü.

Karaman, G., ve Güngör-Aytar, A. (2016). Erken Okuryazarlık Becerilerini Değerlendirme Aracı'nın (EOBDA) geliştirilmesi. Mersin Üniversitesi Ë̆itim Fakültesi Dergisi, 12(2), 516-541.

Kemaloğlu, Y. (2017). İşitme yetersizliği: tanım, sınıflama, yaygınlık ve nedenleri. Edt: Hasan Gürgür ve Pınar Şafak. İsitme ve Görme Yetresiz̨liğ içinde Bölüm 1 Ankara: Pegem Akademi.

Kujala, T. \& Leminen, M. (2017). Low-level neural auditory discrimination dysfunctions in specific language impairment-A review on mismatch negativity findings. Developmental Cognitive Neuroscience(28), 65-75.

Liebenthal, E., Binder, J., Spitzer, S., Possing, E., \& Medler, D. (2005). Neural substrates of phonemic perception. Cerebral Cortex.

Kuru, N. ve Koç Tüylü, D. (2019) İlkokula hazırlıkta erken okuryazarlık eğitimi. (Ed: Özgül Polat) Adım Adım İlkokula Başlamak: Okula Uyum ve Erken Okuryazarlı Eğitimi içinde Bölüm5. Ankara: Anı Yayıncilik.

Küçükoğlu, E. ve Tunçeli, İ.H.. (2019) İlkokula hazırbulunuşlukta alg1 eğitimi. (Ed: Özgül Polat) Adım Adım Illkokula Başlamak: Okula Uyum ve Erken Okuryaz̧arlı Eğitimi içinde Bölüm 6. Ankara: Anı Yayıncilik.

Martin, N., \& Brownell, R. (2005). Test of Auditory Processing Skills Manuel. California USA: Academic Theraphy Publications.

May, M. (2007). Sensation and perception. New York: Infobase Publishing.

Milli Eğitim Bakanlı̆̆1 Temel Eğitim Genel Müdürlüğü. (2013) Okul Öncesi Eğitim Programı. https://tegm.meb.gov.tr/dosya/okuloncesi/ooproram.pdf adresinden 20 Eylül 2013 tarihinde erişilmişti.

Milli Ĕğitim Bakanlığı Strateji Geliştirme Başkanlığı. (2016). Milli Eğitim İstatistikleri Örgün Eŭgitim 2015/'16.https://sgb.meb.gov.tr/meb_iys_dosyalar/2016_03/30044345_meb_istatistikle ri_orgun_egitim_2015_2016.pdf adresinden 10 Hazirazn 2015 tarihinde erişilmiştir.

Milli Eğitim Bakanlığ Talim Terbiye Kurulu. (2016). 07.03.2016 tarih ve 12 saynl İlkëğretim Türkese Dersi (1, 2, 3, 4, 5, 6, 7 ve 8. Simflar) Öğretim Programında Deģ̆̈siklik Yapılması'na ilişskin karar. 
https://ttkb.meb.gov.tr/kurulkararlari/fihristler/fihrist_2016.pdf adresinden 10 Hazirazn 2015 tarihinde erişilmiştir.

Møller, A. R. (2013). Hearing: Anatomy, Physiology, and Disorders of the Auditory System. San Diego, CA: Plural Publishing, Inc.

Moore, B. C. (2014). Auditory Processing Of Temporal Fine Structure: Effects Of Age And Hearing Loss. 5 Toh Tuck Link, Singapore: World Scientific Publishing Co. Pte. Ltd.

Niemitalo-Haapola, E., Haapala, S., Kujala, T., Raappana, A., Kujala, T., \& Jansson-Verkasalo, E. (2017). Noise equally degrades central auditory processing in 2- and 4-year-old children. Journal of Speech, Language, and Hearing Research(60), 2297-2309.

Otaiba, S., Connor, C., Lane, H., Kosanovich, M., Schatscneider, C., Dyrlund, A., . . Wright, T. (2008). Reading First kindergarten classroom instruction and students' growth in phonological awareness and letter naming-decoding fluency. Journal of School Psychology, 46, $281-314$

Polat, Ö. (2013). Marmara İlkëğretime Hazır Oluş Ölçeği El Kitabı. İstanbul.

Polat-Unutkan, Ö. (2003). Marmara İlköğretime Haæur Oluş Ölçeğínin gelistirilmesi ve standizasyonu. İstanbul: Marmara Üniversitesi Eğitim Bilimleri Enstitüsü.

Polat-Unutkan, Ö. ve Oktay, A. (2004) Marmara İlköğretime Hazır Oluş Ölçeğinin geliştirilmesi ve standardizasyonu. (Development and standardization of Marmara School Readiness Inventory) First International Pre-School Education Congress. Marmara University. İstanbul: Yapa Publishing., 336-352.

Sarı, B., ve Aktan Acar, E. (2013). Erken Çocukluk Dönemi Fonolojik Duyarlılık Ölçeği’nin (EÇDFDÖ) geliştirilmesi ve psikometrik özellikleri. Kuram ve Uygulamada Eğitim Bilimleri, 13(4), 2195-2215.

Sertel Berk, Ö., ve Özkul, H. (2014). Duyum ve ALgz Psikolojisi. İstanbul: Nobel Tip Kitapevleri.

Sönmez, V., ve Alacapınar, F.G. (2017). Örneklendirilmişs Bilimsel Arasstırma Yöntemleri. Ankara: Anı Yayınc1lik.

Şencan, H. (2005). Sosyal ve Davranışsal Ölçümlerde Güvenirlike ve Geçerlilik. Ankara: Seçkin Yayıncılık.

Tavşancıl, E. (2002). Tutumlarn Ölçülmesi ve SPSS ile Veri Analiz̧i. Ankara: Nobel Yayınları.

Tepeli, K., Er Şahin, S., ve Erbay, F. (2018). Selçuk İşitsel Muhakeme ve İşlem Becerileri Testi (SIMIBT)'nin geliştirilmesi ve geçerlik-güvenirlik çalışması. International Journal of Education Sciences and Learning Technology, 1(2), 33-42. 
Thompson, E., Carr, K., White-Schwoch, T., Otto-Meyer, S., \& Kraus, N. (2017). Individual differences in speech-in-noise perception parallel neural speech processing and attention in preschoolers. Hearing Research(344), 148-157

Vanvooren, S., Poelmans, H., De Vosa, A., Ghesquière, P., \& Wouters, J. (2017). Do prereaders' auditory processing and speech perception predict later literacy? Research in Developmental Disabilities(70), 138-151.

White-Schwoch, T., Carr, K., Thompson, E., Anderson, S., Nicol, T., Bradlow, A., . . Kraus, N. (tarih yok). Auditory processing in noise: A preschool biomarker for literacy. PLOS Biology, 13(7), 1-17.

Yazıcıŏglu, Y., ve Erdoğan, S. (2004). Spss uygulamah bilimsel araștırma yöntemleri. Ankara: Detay Yayınlar1.

Yurdugül, H. (2005). Ölçek geliştirme çalışmalarında kapsam geçerlik indekslerinini kullanılması.

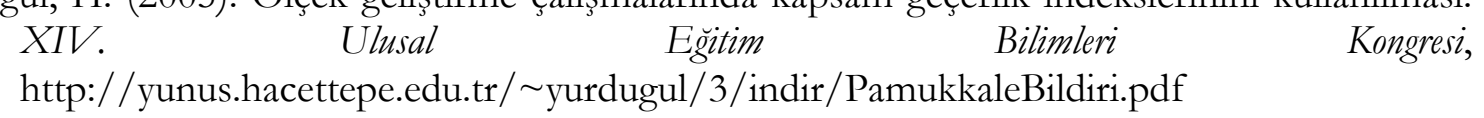

